Review

\title{
Liver Immune Microenvironment and Metastasis from Colorectal Cancer-Pathogenesis and Therapeutic Perspectives
}

\author{
Xuezhen Zeng ${ }^{1,2,3}$, Simon E. Ward ${ }^{4} \mathbb{D}$, Jingying Zhou ${ }^{5, *} \mathbb{\infty}$ and Alfred S. L. Cheng ${ }^{5, *}$ \\ 1 Department of Liver Surgery, The First Affiliated Hospital, Sun Yat-sen University, Guangzhou 510080, China; \\ zengxzh7@mail.sysu.edu.cn \\ 2 Department of Pharmacy, The First Affiliated Hospital, Sun Yat-sen University, Guangzhou 510080, China \\ 3 Institute of Precision Medicine, The First Affiliated Hospital, Sun Yat-sen University, \\ Guangzhou 510080, China \\ 4 Medicines Discovery Institute, Cardiff University, Cardiff CF10 3AT, UK; WardS10@cardiff.ac.uk \\ 5 School of Biomedical Sciences, The Chinese University of Hong Kong, Hong Kong 999077, China \\ * Correspondence: zhoujy@cuhk.edu.hk (J.Z.); alfredcheng@cuhk.edu.hk (A.S.L.C.); \\ Tel.: +852-3943-9843 (A.S.L.C.)
}

check for updates

Citation: Zeng, X.; Ward, S.E.; Zhou, J.; Cheng, A.S.L. Liver Immune Microenvironment and Metastasis from Colorectal Cancer-Pathogenesis and Therapeutic Perspectives. Cancers 2021, 13, 2418. https://doi.org/ $10.3390 /$ cancers 13102418

Academic Editor: Antonio V. Sterpetti

Received: 24 March 2021

Accepted: 12 May 2021

Published: 17 May 2021

Publisher's Note: MDPI stays neutral with regard to jurisdictional claims in published maps and institutional affiliations.

Copyright: (c) 2021 by the authors. Licensee MDPI, Basel, Switzerland. This article is an open access article distributed under the terms and conditions of the Creative Commons Attribution (CC BY) license (https:// creativecommons.org/licenses/by/ $4.0 /)$.
Simple Summary: Liver metastasis remains the major contributor in colorectal cancer-related death. It has become clear that the unique immune features of liver microenvironment take part in many steps of metastatic cascade, from pre-metastatic niche formation, tumor cell colonization to metastatic tumor establishment. Therefore, better understanding of mechanisms orchestrating the formation of a hospitable hepatic metastatic niche is necessary for the development of effective therapies. This review summarizes the current understandings of the critical role of liver immune microenvironment in metastasis development and provides therapeutic perspective on targeting the metastasis-prone microenvironment.

Abstract: A drastic difference exists between the 5-year survival rates of colorectal cancer patients with localized cancer and distal organ metastasis. The liver is the most favorable organ for cancer metastases from the colorectum. Beyond the liver-colon anatomic relationship, emerging evidence highlights the impact of liver immune microenvironment on colorectal liver metastasis. Prior to cancer cell dissemination, hepatocytes secrete multiple factors to recruit or activate immune cells and stromal cells in the liver to form a favorable premetastatic niche. The liver-resident cells including Kupffer cells, hepatic stellate cells, and liver-sinusoidal endothelial cells are co-opted by the recruited cells, such as myeloid-derived suppressor cells and tumor-associated macrophages, to establish an immunosuppressive liver microenvironment suitable for tumor cell colonization and outgrowth. Current treatments including radical surgery, systemic therapy, and localized therapy have only achieved good clinical outcomes in a minority of colorectal cancer patients with liver metastasis, which is further hampered by high recurrence rate. Better understanding of the mechanisms governing the metastasis-prone liver immune microenvironment should open new immuno-oncology avenues for liver metastasis intervention.

Keywords: liver immune microenvironment; colorectal cancer liver metastasis; therapeutic perspectives

\section{Introduction on Colorectal Cancer (CRC) Liver Metastasis \\ 1.1. Liver Tropism in Cancer Metastasis}

Cancer metastasis is the major obstacle to successful management of malignant disease and accounts for approximately $90 \%$ of cancer related mortality [1]. Interestingly, the formation of metastasis favors a few target organs, including liver, bone marrow, etc. Liver is one of the most common metastatic sites for various malignancies [2], including colorectal cancer, pancreatic cancer, gastric cancer, breast cancer, and melanoma, etc. Metastatic tumor 
cells usually invade into the liver parenchyma for seeding and progress. However, the mechanisms underlying liver tropism in cancer metastasis remain largely unknown.

Numerous studies addressed that the unique structure and characteristic of liver that it enriches in vessels with high permeability and has unparalleled dual blood connectivity, and the immunosuppressive microenvironment, make it vulnerable to the seeding of disseminated tumor cells [3]: The dual vascular supply of the liver by the systemic arterial and portal venous system enhances the entrapment of circulating tumor cells, explaining increased incidence of liver metastasis in patients with gastrointestinal cancers; In addition, the immune microenvironment in liver has evolved to dampen immunity to neoantigens entering the liver from the gut via portal vein so as to avoid damage to the liver [4].

The liver is comprised of heterogeneous cell populations, including parenchymal hepatocytes, and nonparenchymal cells like hepatic stellate cells, infiltrated or resident immune cells, and liver sinusoidal endothelial cells. Accumulating evidence shows that both the parenchymal and the nonparenchymal cells play a role in the process of metastatic cascade, including facilitating acquisition of epithelial-mesenchymal transition (EMT) phenotype, migration to liver, seeding, and colonization as well as the decision to undergo dormancy versus outgrowth [3].

\subsection{Clinical Significance of CRC Liver Metastasis}

Among all types of cancer, CRC is the most common cancer that predominantly metastasizes to the liver [5]. CRC is the fourth most common and third most deadly malignancy worldwide with a steadily rising incidence rate in developing countries [6]. Approximately $50 \%$ of CRC patients have already developed liver metastases at diagnosis, and $40-50 \%$ of patients will develop liver metastasis after primary tumor resection within 3 years [7-9]. Consequently, emergence of liver metastasis has been used as prognostic marker for CRC. The 5-year survival rate was dramatically decreased to 10-20\% compared to $80-90 \%$ of patients with only localized CRC [10].

CRC liver metastases mainly exhibit two distinct histopathological growth patterns (HGPs) at the interface between the tumor and surrounding liver parenchyma, namely, desmoplastic type (dHGP) and non-desmoplastic type [11]. dHGP is characterized by increased angiogenesis, and the new blood vessels appear leaky and are functionally impaired with fibrin deposits. Non-desmoplastic type includes replacement $(r)$ and the pushing ( $p$ ) pattern. In rHGP, the tumor permeates between the liver hepatocytes, without disruption of the normal architecture, while the tumor expands and compresses the surrounding hepatocytes in pHGP. Interestingly, the distribution of immune cells was different among three HGPs [12]. Increased cytotoxic $\mathrm{CD}^{+} \mathrm{T}$ cells, $\mathrm{CD}^{+} 5^{+}, \mathrm{CD}^{2} \mathrm{~A}^{+}$, Kappa/Lambda, and Self-ligand receptor of the signaling lymphocytic activation molecule family 7 (SLAMF7) ${ }^{+}$cells and a higher $\mathrm{CD}^{+} / \mathrm{CD}^{+}$ratio were observed in dHGP compared to other HGPs [13-15]. Additionally, multiple studies showed that desmoplastic type have improved prognosis compared to non-desmoplastic type [11,13,16-18].

Although the metastatic tumor of a small proportion of colorectal cancer liver metastasis patients can be removed by surgical resection, the 5-year survival rate is still, disappointingly, only around 36\% [19], with $75 \%$ of patients undergoing rapid relapse after resection [20]. The survival rate after resection depends on a number of variables: liver metastasis, tumor size, node-positive primary cancer, preoperative carcinoembryonic antigen level. Some other additional therapies, like anti-epidermal growth factor receptor (EGFR) or anti-vascular endothelial growth factor (VEGF) (e.g., cetuximab, bevacizumab) have been used in treating CRC, but the financial burden is very high while the efficacy is still modest [21,22]. Immunotherapy has revolutionized the treatment of cancer, yet it is currently not widely applicable to CRC liver metastasis but show great potential in preclinical studies and clinical translation $[23,24]$. 


\subsection{Pathogenesis of CRC Liver Metastases}

Although cancer metastasis is the major cause of cancer related mortality, metastasis remains one of the poorly characterized aspects of cancer biology. Cancer metastasis is a sequential series of events called "metastatic cascade", during which locally proliferating cancer cells acquire the invasive capability and translocate to the circulation, migrate to the distant organ, colonize, and form metastases eventually [25]. In CRC liver metastasis, mutations including KRAS, TP53, APC, PIK3CA, NRAS, BRAF, and SMAD4, etc., accompanied by genomic and epigenomic instability initiate CRC development and acquire the invasive phenotype [26]. Cooperating with immune cells via secretion of cytokines, chemokines, growth factors, and proteases, CRC cells reshapes the favorable tumor microenvironment to facilitate CRC liver metastasis [27]. The immune cells actively interact with CRC cells at every step of the metastatic cascade, including modulating tumor-infiltrating leukocytes to evade immune surveillance, formation of pre-metastatic niche, enhancing CRC extravasation and intravasation, protection of circulating or arrested CRC cells, promoting colonization, and reactivating dormant metastatic CRC cells in liver, which supports successful liver metastasis [28,29].

In this review, we summarize the underlying mechanisms of CRC liver metastasis facilitated by liver immune microenvironment in the process of liver metastatic cascade, especially the pre-metastatic niche formation and CRC colonization and propagation in liver. Furthermore, we discuss how the reciprocal interaction between immune cells and CRC cells influence liver metastasis formation and response to therapy, and discuss the potential of therapies that target the liver immune microenvironment to treat CRC liver metastasis.

\section{Liver Immune Microenvironment for CRC Liver Metastasis}

The unique and complex microenvironment of liver with enriched vessel permeability and dampened immune response to neoantigens makes it a fertile soil for cancer cell metastasis. In this section, we will review the hepatocyte-derived factors, non-parenchymal cells, and various immune cells that cooperate in the liver to form a metastasis-prone microenvironment for CRC cells.

\subsection{Hepatocyte-Derived Factors}

\subsubsection{Inflammatory Cytokines/Chemokines and Growth Factors}

A substantial number of studies has demonstrated that tumor derived factors including cytokines and chemokines drive pre-metastatic niche formation in the distant organ to support the incoming of metastatic tumor cells. The premetastatic niche protects tumor cells from immune attack by cytotoxic lymphocytes, which nullifies the efficacy of immunotherapy and facilitates metastasis [30-32]. In fact, not only tumor cells but also parenchymal hepatocytes play a role in regulating liver metastasis. Recently, an interesting study showed that during early pancreatic cancer development, non-malignant cells secreted IL-6 to activate signal transducer and activator of transcription 3 (STAT3) signaling in hepatocytes. Subsequently, these hepatocytes produced serum amyloid A1 and A2 (SAA) to induce myeloid cell accumulation and alter the fibrotic microenvironment in the liver to establish the pre-metastatic niche. Consistently, overexpression of SAA and activation of STAT3 were observed in the liver of pancreatic cancer and colorectal cancer liver metastasis patients. In addition, circulating SAA levels were significantly higher in liver metastasis patients, which correlated with poor survival [33]. Another study also showed that the expression of hepatic cytokines (tumor necrosis factor $\alpha$ (TNF- $\alpha$ ), IL-1 beta, IL-6, IL-10) and other factors noted to be involved in the colonization of CRC cells including intercellular adhesion molecule 1 (ICAM-1), chemokine (C-C motif) ligand 2 (CCL-2), CCL-7, matrix metalloproteinase-2 (MMP-2), and MMP-9 were significantly increased in alcohol-injured liver, and positively correlated with rate and burden of CRC liver metastases [34]. Moreover, hepatocytes release multiple factors, such as insulin-like growth factor 1 (IGF-1), hepatocyte growth factor-like protein/macrophage stimulating-protein (HGFL), and hepatocyte-derived heregulin (HRG), which can induce tumor cell growth, invasion, and metastasis through different mechanisms [35-37]. It was also 
reported that tumor activated hepatocyte and myofibroblast could affect the phenotype of primary CRC cell by upregulating liver metastatic gene expression (e.g., S100P, cadherin-H1, osteopontin, transforming growth factor beta (TGF- $\beta$ ), thioredoxin-1). For example, TGF- $\beta$ induced the expression of extracellular matrix protein by colon cancer cells, which enhances their aggressiveness and metastatic properties [38] (Figure 1).

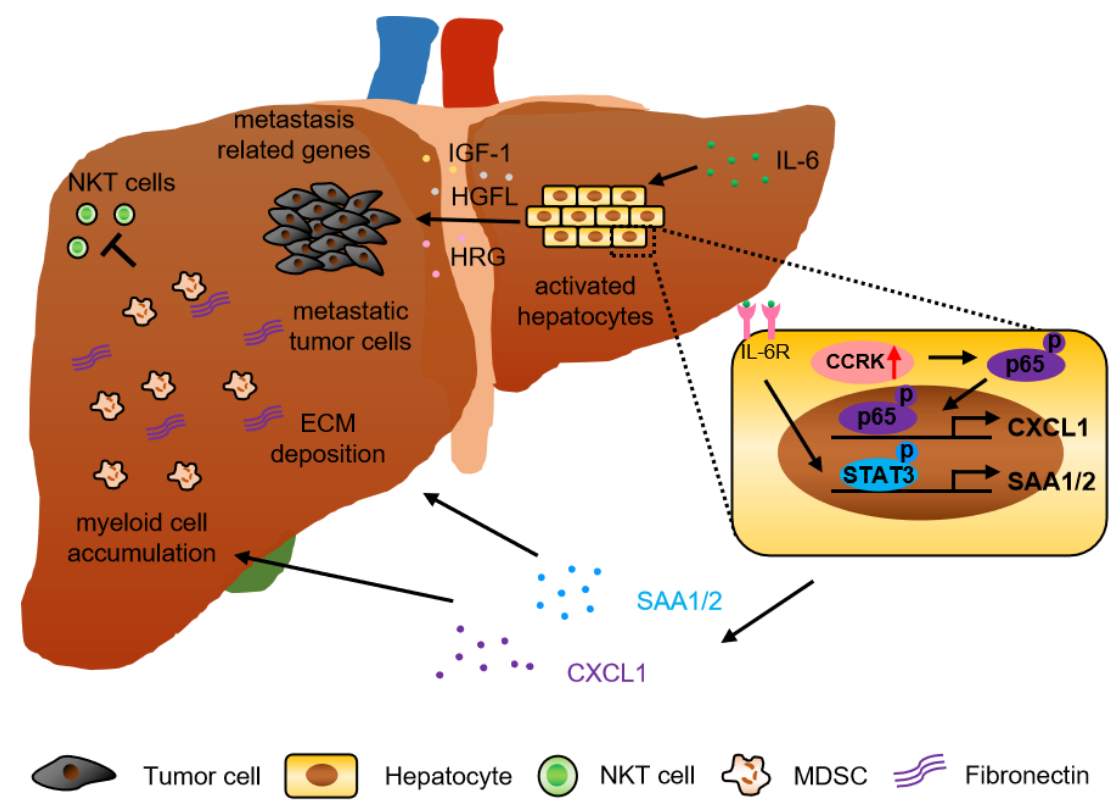

Figure 1. Hepatocyte-derived factors drive pre-metastatic niche formation for cancer metastasis. Schematic diagram showing the effects of hepatocyte-derived factors on establishment of pre-metastatic niche in CRC liver metastasis. Hepatocytes activated by primary tumor cells upregulate CXCL1 and SAA1/ 2 expression to increase myeloid cell accumulation and ECM deposition, which facilitates cancer liver metastasis. In addition, these hepatocytes also secrete multiple factors like IGF-1, HGFL, HRG to promote metastatic tumor growth.

\subsubsection{Cyclin-Dependent Kinases (CDKs)}

CDKs play pivotal roles in the regulation of cell division and transcription in response to extra- and intracellular cues and deregulation of CDKs is a hallmark of cancer [39]. A recent case report showed that a CDK4/6 inhibitor together with hormonal therapy successfully managed visceral metastases and provided long-term survival in a patient with breast cancer liver metastases [40]. CDK8 has been reported to be overexpressed in colon cancer, and inhibition of CDK8 did not affect colon cancer cell growth but significantly suppressed colon cancer liver metastasis. Mechanistically, CDK8 downregulated the expression of TIMP metallopeptidase inhibitor 3 (TIMP3) via TGF $\beta$ /SMAD-driven expression of a TIMP3-targeting microRNA, miR-181b, which consequently increased MMP expression. In addition, CDK8 induced Mmp3 transcription in murine or MMP9 in human colon cancer cells through Wnt/ $\beta$-catenin signaling pathway [41]. MMPs play pivotal roles in various biological processes, including matrix degradation, angiogenesis, cell adhesion, growth factor receptor signaling, apoptosis, ECM remodeling, and immune regulation, which facilitated cancer progression and metastasis [42].

Our previous study also reported that cell cycle-related kinase (CCRK, also called CDK20) activated nuclear factor-kappa B (NF-KB) signaling in hepatocytes (parenchymal cells) to increase the polymorphonuclear myeloid-derived suppressor cell (PMN-MDSC)trafficking chemokine C-X-C motif ligand 1 (CXCL1) expression in the liver. Increased CXCL1 recruited PMN-MDSC and reduced natural killer T (NKT) cells in liver to form the pre-metastatic niche for melanoma and colorectal cancer liver metastasis in CCRK transgenic mice. Accordingly, CRC liver metastasis patients exhibited hyperactivation of hepatic CCRK/NF-KB/CXCL1 signaling, which was associated with accumulation of PMN- 
MDSCs and a paucity of NKT cells compared to healthy liver transplantation donors [43] (Figure 1). This study highlighted the parenchymal-immune cell crosstalk in shaping the liver immune microenvironment for CRC liver metastasis.

Collectively, these studies demonstrated that in addition to tumor derived factors, hepatocytes also participated in the formation of pre-metastatic niche for cancer metastasis.

\subsection{Liver Non-Parenchymal Cells}

In addition to hepatocyte-derived factors, increasing evidence suggests that nonparenchymal cells, such as liver resident fibroblast hepatic stellate cells (HSCs), liver resident macrophage Kupffer cells (KCs), liver sinusoidal endothelial cells (LSECs), and liver infiltrating immune cells around the hepatocytes also have critical roles in multiple stages during the development of CRC liver metastases either by direct or indirect cell-tocell interaction.

\subsubsection{Hepatic Stellate Cell (HSC) and Cancer Associated Fibroblasts (CAF)}

HSCs, also known as perisinusoidal cells, are resident pericytes localized in the perisinusoidal space of Disse, accounting for $\sim 10 \%$ of all resident cells in liver [44]. HSCs have various functions in normal and injured liver, and play a pivotal role in premetastatic niche. Our previous study showed that activated HSCs induced monocyte-intrinsic p38 MAPK pathway to trigger enhancer reprogramming for M-MDSC differentiation and immunosuppression, indicating the non-parenchymal-immune cell crosstalk in HCC development. In addition, the accumulation of M-MDSC in fibrotic liver was associated with reduced cytotoxic T cells and HCC progression [45]. Besides, a study also showed that pancreatic ductal adenocarcinoma (PDAC)-derived exosomes containing macrophage migration inhibitory factor (MIF) were taken up by KCs and subsequently activated resident HSC via TGF- $\beta$, leading to upregulation of fibronectin (Figure 2, in space of disse). This fibrotic environment further recruited tumor associated macrophages in liver premetastatic niche and facilitated the adhesion of disseminated tumor cells [31]. In addition, activated HSC secreted periostin to enhance CRC and endothelial cell survival in liver via the $\alpha \mathrm{v} \beta 3$ Integrin-Akt/PKB pathway [46]. Co-injection of HSC with CRC cells significantly promoted liver metastasis by enhancing angiogenesis [47].

Meanwhile, as a type of fibroblast, activated HSCs also preserve the metastatic-prone features of common cancer associated fibroblasts (CAF). CAF is one of the most abundant stromal cells in the tumor microenvironment, which can promote tumor growth, angiogenesis, and metastasis. In CRC, the distribution of CAFs in primary CRC has been demonstrated to be associated with malignant potential and prognosis of CRC patients [48]. Fibroblast activation protein- $\alpha$ (FAP) derived from CAFs was reported to be related to liver metastasis and poor clinical outcome [49]. Mechanistically, CAFs facilitated liver metastasis by supporting CRC cells' adhesion and promoting CRC cell stemness and drug resistance. CAFs secreted hepatocyte growth factor (HGF) to induce CD44 expression on CRC cells via HGF/MET / AKT signaling, which promoted adhesion and migration of CRC cells [50]. Moreover, TGF $\beta 1$ induced adhesion of CRC cells to CAFs, and co-migration of CAFs and CRC cells remarkably enhanced liver metastasis [51]. CAFs can also directly transferred exosomes (containing miR-92a-3p) to CRC cells, which subsequently activated Wnt/ $\beta$ catenin pathway and inhibited mitochondrial apoptosis, contributing to cell stemness, EMT, metastasis, and 5-FU/L-OHP resistance in CRC [52]. Reciprocally, CRC cells also induced and modified CAFs to facilitate metastasis. CRC cells activated HSCs and induced their differentiation into CAFs [53]. Similarly, elevated carcinoembryonic antigen (CEA) level by CRC cells activated and transformed fibroblast to CAF phenotype, which remodeled the extracellular matrix and promoted CRC cells adhesion and liver metastasis [54]. In addition, it was reported that the crosstalk between SMAD4 deficient CRC cells (instead of SMAD4 proficient CRC cells) and CAFs induced bone morphogenetic protein 2 (BMP2) expression in CAFs and consequently promoted CRC invasiveness and liver metastasis in preclinical model [55]. Dysregulation of BMP signaling in CAF predicted and modified 
CRC progression and prognosis. Targeting CAF by regulation of BMP signaling reduced CRC liver metastasis [56].

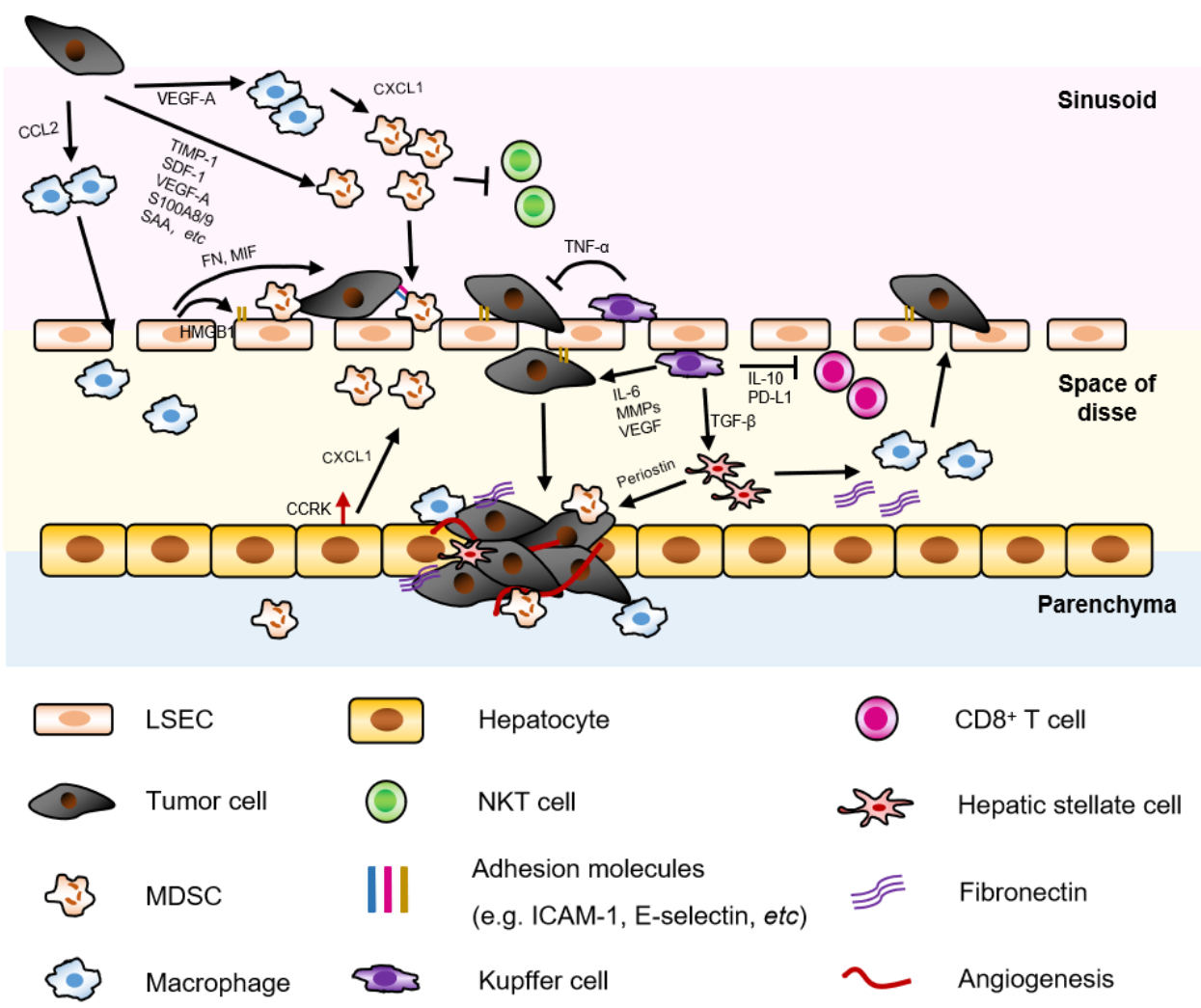

Figure 2. Immunoregulation of disseminated tumor cells by metastatic-prone liver immune microenvironment. The successful colonization of colorectal cancer cells in liver depends on the interaction between tumor cells and the liver immune microenvironment. The primary tumor cells secrete multiple factors to recruit MDSCs and macrophages in liver, which suppresses NKT cells, facilitates the arrest and invasion of the tumor cells and promotes angiogenesis. LSECs support the arrest, retention, and transmigration of tumor cells by the expression of adhesion molecules, and secrete fibronectin (FN) and MIF to induce EMT phenotype in CRC cells. Kupffer cells can both inhibit tumor cell growth by secretion of TNF- $\alpha$ and support tumor cell metastasis via suppression of CD8+T cells, activation of HSC, and promoting tumor cell invasion. The activated HSCs upregulate fibronectin, recruit macrophage to promote adhesion of disseminating tumor cells, and secrete periostin to enhance angiogenesis.

\subsubsection{Liver Sinusoidal Endothelial Cell (LSEC)}

LSECs are the major resident non-parenchymal cells in liver, which line the low shear, sinusoidal capillary channels of the liver. LSECs have vital immunological functions like antigen presentation, leukocyte recruitment, and physiological functions like filtration and endocytosis [57]. When the disseminating tumor cells arrive at the liver through the circulation, they are arrested and trapped in the sinusoidal capillaries in liver. Here, some tumor cells are killed by the immunosurveillance of tissue resident KCs and NK cells [58] and the remaining surviving tumor cells extravasate into the perisinusoidal space (space of Disse). In this process, LSECs upregulate the expression of cell adhesion molecules, such as vascular cell adhesion molecule 1 (VCAM-1), intercellular cell adhesion molecule 1 (ICAM-1), and E-selectin to support the arrest, retention, and transmigration of the tumor cells. Multiple preclinical studies showed that inhibition of adhesion molecules by targeting integrin $\beta 2$ (ligand of ICAM-1) [59], blockade of adhesion molecules [60], and disruption of inflammatory TNF $\alpha / \mathrm{TNF}$ receptor 2 (TNFR2) signaling [61,62], Notch signaling [63] reduced liver metastasis.

In addition, the reciprocal crosstalk between tumor cells and LSECs also enhance survival and metastatic potential of tumor cells and promote angiogenesis. Ligands 
such as CD44, sLewA, and sLewX expressed on tumor cells interacted with E-selectin on inflamed LSECs, which promoted CRC liver metastasis $[64,65]$ and further increased adhesion molecule expression on LSECs by upregulating high-mobility group box 1 (HMBG1) release [66]. Simultaneously, LSECs secreted fibronectin and macrophage migration inhibitory factor (MIF) that could induce EMT phenotype in CRC cells resulting in increased invasion and migration of CRC cells into the liver parenchyma [67] (Figure 2, in sinusoid/space of disse).

\subsubsection{Kupffer Cell}

Kupffer cells (KC) are resident macrophages in the liver, which play a dual role in the tumor microenvironment of liver metastasis. On one hand, KCs exert tumoricidal activity by phagocytosis, releasing oxygen metabolites, cytotoxic cytokines, and secreting proteases [68-71]. During the initial stage of CRC liver metastasis, KCs secrete TNF- $\alpha$ in liver, contributing to metastasis control [61]. On the other hand, KCs can induce cell adhesion molecule expression on LSECs, which helps the adhesion of disseminated tumor cell arrest in liver, and produces factors (e.g., IL-6, MMPs, VEGF, etc.) that promote tumor cell invasion, proliferation, and angiogenesis. In the tolerant state, $\mathrm{KC}$ s can also release inhibitory cytokine IL-10, induce regulatory T cells (Tregs), and express T cell inhibitory molecule programmed cell death 1 ligand (PD-L1), which ameliorates anti-tumor immunity [72] (Figure 2, in sinusoid/space of disse). Collectively, these studies highlighted a complex non-parenchymal/immune cell-immune cell crosstalk in liver microenvironment.

\subsection{Liver-Infiltrating Immune Cells}

\subsubsection{Neutrophil and Myeloid-Derived Suppressor Cell (MDSC)}

Neutrophils are innate immune cells and show functional plasticity driven by multiple factors in cancer, depending on different microenvironments $[73,74]$. Various factors have been demonstrated to support the recruitment and accumulation of neutrophils and PMN-MDSC in liver metastases. It was shown that tumor derived tissue inhibitor of metalloproteinases (TIMP)-1 level was increased in CRC patients and correlated with liver metastasis [75]. Mechanistically, TIMP1 upregulated stromal-derived factor (SDF) 1 to recruit neutrophils to the liver, which facilitated CRC liver metastasis. Inhibition of SDF-1/CXCR4 axis or depletion of neutrophils significantly reduced liver metastasis in mice [75]. Additionally, lysyl oxidase-like 4 (LOXL4) protein was demonstrated to be upregulated in neutrophils in CRC liver metastases with replacement HGP compared to desmoplastic type of liver metastases and the adjacent normal liver, which was associated with resistance to neoadjuvant anti-angiogenic therapy [76]. The expression of LOXL4 was significantly higher in circulating neutrophils of these patients compared with healthy control, and can be induced by stimulation with lipopolysaccharide and TNF- $\alpha$. These studies suggested the multifunctional role of neutrophils in liver metastases. Another study showed that CRC cells overexpressed VEGF-A to induce CXCL1 secretion from macrophages, which subsequently recruited CXCR2 positive MDSC in liver to form the metastatic niche [77]. Similarly, it was showed that secretion of OPN, MMP9, S100A8, S100A9, SAA3, and VEGFA were increased in a CT26FL3 liver metastasis mouse model to enhance bone marrow derived-cell recruitment in liver for pre-metastatic niche formation [78]. Our previous study also found that CCRK-CXCL1 mediated PMN-MDSC recruitment in liver and reduced NKT cell infiltration were significantly correlated with melanoma and CRC liver metastasis. Inhibition of PMN-MDSC restored NKT cell infiltration and ameliorated liver metastasis [43]. In a mouse colon cancer and lung cancer liver metastasis model, accumulation of MDSC was associated with liver metastasis dependent on TNFR2 signaling. Disruption of TNFR2 signaling significantly reduced MDSC accumulation and liver metastasis [62]. Clinically, it was also demonstrated that circulating MDSC level was positively correlated with metastatic tumor burden in various types of solid tumors [79]. 
In addition, neutrophils can also promote liver metastasis in an immune-independent manner. Neutrophils arrested on LSEC in liver sinusoids increased tumor cell adhesion by interaction of CD11b/CD18 (Mac-1) on neutrophils and ICAM on tumor cells, acting as a bridge between disseminating tumor cells and liver parenchyma [80] (Figure 2, in sinusoid/space of disse/parenchyma).

\subsubsection{Monocyte, Tumor Associated Macrophage (TAM) or Metastasis-Associated Macrophage (MAM)}

Macrophages are plastic and can polarize to tumoricidal or pro-tumorigenic macrophages under different microenvironments. In liver metastases, monocytes and TAMs or MAMs were recruited in liver by tumor cells via CCL2 secretion. And adoptive transfer of inflammatory monocytes preferentially migrated to the metastatic sites and differentiated into MAMs [81]. Recruitment of macrophages in the liver facilitated liver metastasis by inducing liver fibrosis and immunosuppression [82,83]. CCR2 antagonists or knockout of CCL2 in tumor cells significantly reduced metastatic tumor burden $[81,84,85]$. In a mouse CRC liver metastasis model, loss of Ndrg2 ( $\mathrm{N}$-myc downstream-regulated gene 2) gene in macrophage shifted TAM polarization to M1 phenotype and thus alleviated CRC liver metastasis [86] (Figure 2, in sinusoid/space of disse/parenchyma). However, it is difficult to differentiate the effect of inhibiting tumor cell seeding or growth in most studies using animal models, when reduced liver metastasis was observed.

\subsubsection{NK Cell}

NK cell accounts for $50 \%$ of the liver lymphocyte population and exhibits anti-tumor function mediated by the release of cytotoxic granules, TNF-related apoptosis-inducing ligand (TRAIL) and Fas ligand (FasL) [87]. As part of innate immunity, NK cells can exert killer function towards transformed and stressed cells. Besides, NK cells can also modulate innate and adaptive immunity by secretion of chemokine and cytokine $[88,89]$. Substantial evidence shows that NK cell plays a pivotal role in controlling cancer metastasis [90]. In a preclinical mouse CRC liver metastasis model, NK cells were demonstrated to restrain CRC liver metastasis. However, the function of NK cells was impaired in hepatic metastases compared to NK cells in healthy livers. More interestingly, the differentiation of NK cells was instructed by signals from the liver microenvironment bearing metastatic tumors, indicating the complex crosstalk between NK cells and CRC liver metastases [91]. Further mechanistic study revealed that CRC liver metastases produced lactate to modulate the $\mathrm{pH}$ of the tumor microenvironment, which induced mitochondrial stress and apoptosis of liver-resident NK cells migrating towards the tumor, leading to metastases outgrowth [92]. In addition, nucleotide-binding oligomerization domain family pyrin domain containing 3 (Nlrp3) inflammasome-IL-18 pathway could also regulate the maturation, surface expression of the death ligand FasL, and tumoricidal activity of hepatic NK cells. Thus, Nlrp3 deficiency significantly impaired effective NK-cell-mediated tumor attack required to suppress CRC liver metastasis [93]. Moreover, TRAIL-expressing NK cells were proved to be important in suppressing liver metastasis. Neutralization of TRAIL using monoclonal antibody abolished NK cell-mediated metastasis control [94]. Clinically, it was shown that NK cell infiltration combined with $\mathrm{CD} 8^{+} \mathrm{T}$ cells has enhanced the prognosis of $\mathrm{CRC}$ patients, indicating a potential supporting role for NK cells in the anti-CRC effects of CD8+ T cells [95].

\subsubsection{NKT Cell}

NKT cells are innate-like lymphocytes that share properties of both NK cells and T cells. Similar to NK cells, NKT cells can exert both anti-tumor killer function and modulate immune responses by secretion of cytokines [96]. It has been reported that CXCL16 could promote NKT cell liver infiltration to potently suppress CRC liver metastasis in vivo [97]. Another study further pointed out that gut microbiome used bile acids as a signal to regulate LSEC-derived CXCL16 which recruited NKT cells in liver [98]. Consistently, our recent study demonstrated that CCRK-CXCL1-MDSC axis activation promoted CRC liver 
metastasis through suppression of anti-tumor hepatic NKT cells, while depletion of MDSC could restore hepatic NKT cells and reduce CRC liver metastasis [43]. In comparison, some controversial studies also pointed out that NKT cells exacerbated liver metastasis arising from intraocular melanomas by inhibiting the anti-tumor activity of liver NK cells [99]. Therefore, further studies were needed to investigate the different subsets and functions of NKT cells in the context of liver metastasis derived from different cancer types.

\subsubsection{Regulatory T Cells (Tregs) and Other Cells}

$\mathrm{CD}^{+} \mathrm{FoxP}^{+}$Tregs are immunosuppressive cells that suppressed effector $\mathrm{T}$ cell functions. It has been reported that increased accumulation of Tregs dependent on TNFR2 signaling correlated with colon and lung cancer liver metastasis. Genetically deficient for TNFR2 or TNFR2 antisense oligodeoxynucleotides significantly reduced Tregs and MDSC accumulation and decreased liver metastasis [62]. In a retrospective study, high Treg infiltration predicted poor clinical outcome of CRC liver metastasis patients, suggesting that infiltrating Treg cells support the growth of established CRC liver metastases [100].

In addition, bone marrow-derived VEGFR1-positive progenitors were also recruited to the pre-metastatic niche, and then formed clusters and promoted the adherence and growth of subsequently disseminating tumor cells [101]. These immature myeloid cells also secreted MMP9 to promote tumor cell invasion to the parenchyma [102].

\subsection{Role of Extracellular Matrix (ECM)}

ECM is a structural scaffold comprised by dynamic macromolecules and their regulatory factors [103], which can support outgrowth and treatment resistance of the arrived tumor cells. Proteomic analysis of three sequential CRC liver metastases in one patient found different ECM phenotypes for recurrent metachronous metastases, associated with different grades of malignancy [104]. Different components of ECM have been studied. In CRC liver metastasis patients, fibroblasts in liver increased ECM stiffening, which enhanced angiogenesis and promoted drug resistance of anti-angiogenic therapy. Reduction of stiffness largely increased the efficacy of anti-angiogenic therapy [105]. Similarly, preoperative treatment with anti-VEGF therapy markedly enhanced hyaluronic acid (HA, component of ECM) deposition within the tumors. Preclinical models demonstrated that hypoxia drove the remodeling of the ECM and thus increased tumor stiffness and reduced drug perfusion in liver metastases. Depletion of HA could reduce the physical barriers to systemic treatments in CRC liver metastases [106].

Neutrophil extracellular traps (NET), also a component of ECM, are comprised of extracellular fibres, primarily webs of DNA, with associated proteolytic enzymes secreted by neutrophils in response to inflammatory cues that trap and kill invading pathogens. Emerging evidence showed that NET can sequester tumor cells arriving at liver, increase their retention, promote tumor cell proliferation and migration, and thus facilitate metastasis $[107,108]$. It was shown that NET-like structures around metastatic breast cancer cells were observed in both the lungs of mice and clinical breast cancer specimens. Inhibition of NET formation or digestion of NET markedly reduced metastasis [109].

\subsection{Immune Checkpoint Molecules}

Immune checkpoint molecules such as programmed cell death protein 1 (PD-1), cytotoxic T lymphocyte-associated antigen-4 (CTLA4), and T cell immunoglobulin and mucin-domain containing-3 (Tim-3), are negative regulators of the immune system to prevent self-attack. However, this mechanism is utilized by cancers to escape from antitumor immunity. Previous study showed that the expression of PD-L1 was increased in liver metastases compared to primary CRC, indicating different intrinsic microenvironment between primary and metastatic CRC [110], which may help CRC liver metastases escape from immune surveillance. In addition, it was reported that chemotherapy can modulate PD-L1 and TIM-3 expression in CRC liver metastases, suggesting the potential strategy of combined chemo-immunotherapies [111]. Preclinical study showed that dual CTLA4 and 
PD-1 blockade could significantly suppress colon cancer growth and liver metastasis by enhancing T cell responses and M1 macrophage polarization [112].

\section{Therapeutics for CRC Liver Metastasis}

\subsection{Current Therapies for CRC Liver Metastasis}

Over the past few decades, advancements have been made in understanding the potential mechanisms and developing therapies for cancer liver metastasis. Although it has been greatly improved, the overall survival of cancer liver metastasis patients remains low. It is difficult to cure the cancers once they metastasize to other organs. The present therapeutic strategies in use for eradicating metastatic tumors are fundamentally the same as treatment targeting primary tumors. For CRC liver metastasis patients, current therapies for liver metastasis are surgical resection, systemic and localized therapies, and combination regimen is also frequently used.

\subsubsection{Surgical Resection}

Based on multiple retrospective and comparative studies, surgical resection remains the gold standard in treating CRC liver metastasis patients and provides long-term survival [19,113-115]. There are two strategies of surgical resection, namely, simultaneous resection and staged resection. But no significant statistical difference on survival was observed between two types of resection [116]. Generally, patients with good liver function and general condition and without metastasis in other organs except liver, are suitable for surgical resection. In particular cases, when CRC patients developed both liver metastases and small lung metastases, liver metastases can still be resected with lung metastases resected or ablated synchronously/metachronously. In a retrospective study, $99(16 \%)$ of 612 patients survived for ten years after hepatic resection, while $34 \%$ of the 5 -year survivors succumb to cancer related death [117]. Although surgical resection provides better survival, only a minority of patients are resectable when diagnosed [118]. In addition, more than $50 \%$ of patients will still develop local and distant recurrence after resection $[117,119]$.

\subsubsection{Systemic Therapy}

For patients with extensive colorectal cancer metastases to both liver and other organs, systemic chemotherapy is a more appropriate option. The combination of oxaliplatin or irinotecan plus leucovorin and 5-fluorouracil is a frequently used chemotherapy regimen that could significantly improve disease outcome in CRC liver metastasis patients [120-122]. Drugs that target epithelial and vascular endothelial growth factor pathways, such as cetuximab and bevacizumab, are also used to treat these patients [21,22].

Moreover, emerging strategies have been designed to increase the resectability of CRC liver metastasis patients. In these patients with initially unresectable liver metastases, treatment of neoadjuvant chemotherapy may not cure the disease but downstage the tumor, which provides an opportunity for resection. Numerous studies in this field endeavor to increase the eligibility for resection, refining the indications and contraindications for surgery, and improving patient survival [123]. The National Comprehensive Cancer Network (NCCN) guidelines recommend FOLFOX (folinic acid plus fluorouracil and oxaliplatin), FOLFIRI (folinic acid and short-term infusional fluorouracil plus irinotecan), or XELOX (capecitabine and oxaliplatin; also called CAPOX) with or without bevacizumab; FOLFIRI with or without cetuximab or panitumumab; or FOLFOX with or without panitumumab or cetuximab (if RAS wild type) (https:/ / www.nccn.org/professionals/physician_gls/ (accessed on 24 March 2021).). Data showed that $12.5 \%$ of unresectable CRC liver metastasis patients acquired the opportunity to liver resection by chemotherapy and had longer survival with lower operative risk [124,125].

\subsubsection{Localized Therapy}

Localized therapy including radiofrequency ablation (RFA), hepatic artery catheter chemotherapy and chemoembolization and portal vein embolization (PVE), radiation 
therapy, are used in patients with unresectable liver metastases without extrahepatic diseases [126]. Among all the treatment modalities, RFA is more frequently used, for its minimal invasiveness with lower mortality rate, fewer complications, reduced hospital days, and costs compared to other therapies. RFA may not cure the disease for most CRC liver metastasis patients, but relieve or control the disease and improve the quality of life of unresectable patients [126]. Hepatic artery catheter chemotherapy and chemoembolization and portal vein embolization can also be considered as alternative treatments to systemic chemotherapy, which can increase drug delivery in the liver but reduce systemic toxicity and showed improved response rate compared to conventional systemic chemotherapy [127]. Selective internal radiation therapy (SIRT) delivering 90Yttrium microspheres to the hepatic artery is another alternative choice for CRC liver metastasis patients. This treatment achieved a high response rate and encouraging survival in CRC liver metastasis patients [128].

\subsection{Therapeutic Perspectives}

\subsubsection{Targeted Therapy Development, e.g., CDKs}

Although liver metastasis accounts for most cancer related mortality in CRC patients, the underlying mechanisms driving this disease progression remain largely unknown, leading to the lack of effective therapy. A recent case report showed that CDK4/ 6 inhibitors exhibited encouraging clinical outcome in treating metastatic breast cancer and colon cancer [40]. Concordantly, our recent studies demonstrated that as the latest family member of CDK, CCRK is the novel signaling hub exploitable in liver disease [129]. Upregulation of CCRK was observed in multiple cancers, such as HCC and colon cancer, which correlated with tumor staging and poor survival and prognosis [130]. In hepatocellular carcinoma (HCC), CCRK mediates tumor development in different etiologies, including hepatitis B virus infection [131], non-alcoholic fatty liver disease [132], via orchestrating a self-reinforcing circuitry comprising of AR, GSK $3 \beta$, $\beta$-catenin, AKT, EZH2, and NF- $\mathrm{kB}$ signaling, and also facilitate tumor immune evasion [133-135]. Knockout Ccrk in mouse hepatoma significantly enhances the efficacy of immune checkpoint inhibitor by disrupting immunosuppression and unleashing anti-tumor immune response $[135,136]$. In addition, the ectopic expression of CCRK induced by chronic inflammation in liver shapes the immune microenvironment by accumulating immunosuppressive PMN-MDSCs and reduced anti-tumor NKT cells to facilitate CRC liver metastasis [43]. Collectively, CCRK plays a pivotal role in regulating liver microenvironment. Thus, modulation of CCRK may be potential therapy for CRC liver metastasis. Given the ability to design inhibitors of a number of the CDK enzyme family (most notably CDK4/ 6 as highlighted above), then development of a selective inhibitor to target CCRK would be both a feasible and attractive drug development opportunity.

\subsubsection{Immunotherapy Development}

Multiple treatment modalities have been developed to treat CRC liver metastasis; however, the efficacy remains unsatisfying. Most patients relapse after these treatments and succumb to the disease; therefore, more effective therapeutic strategies are desperately needed. In addition, development of effective adjuvant therapy after curative treatment of primary CRC tumor to prevent liver metastasis may be of great clinical significance based on the high occurrence of CRC liver metastasis.

Immunotherapy, including immune checkpoint inhibitors (ICIs), cancer vaccines, and chimeric antigen receptor (CAR) T cell therapy, has achieved promising results in many cancers and revolutionized the treatment of cancer by enhancing anti-tumor immune responses. A recent study showed that anti-PD-L1 monotherapy in patients with metastatic or unresectable CRC with mismatch repair deficiency (dMMR)/microsatellite instabilityhigh (MSI-H) displayed remarkable anti-tumor activity with manageable toxicity [23]. Additionally, a case report showed that patients who progress on anti-programmed cell death protein 1 (PD-1) therapy still respond to combinatory immunotherapies (nivolumab 
plus ipilimumab) [137]. Another phase I clinical trial escalating dosage of CAR-T therapy in metastatic CRC patients also observed potential treatment response in some patients without severe adverse events [24]; however, the efficacy remains limited owing to the inhibitory impact of the tumor immune microenvironment, and many patients still cannot benefit from these treatment $[138,139]$.

As discussed above, the immunosuppressive microenvironment in liver contributes to the generation of pre- and pro-metastatic niches to facilitate cancer liver metastasis development, immune evasion, and affect treatment response. A preclinical study showed that CAR T-cell therapy in conjunction with reduction of Tregs and MDSCs hindered CRC growth [140,141], indicating that combination of immunotherapy and targeting the immunosuppressive immune microenvironment may be potentially effective in treating CRC liver metastasis or as adjuvant therapy to prevent liver metastasis.

\subsection{Current Clinical Trials}

Several therapeutic strategies are under investigation in clinical trials, including chemotherapy, targeted therapy, radiotherapy, ablation, surgery, immunotherapy, and more frequently, the combination of a few therapies (Figure 3). Current ongoing clinical trials for CRC liver metastasis are listed in Table 1. Chemotherapy (either systematically or locally administered) combined with other therapies remains the major strategy in clinical trials. Many studies reported that neoadjuvant chemotherapy could convert unresectable liver metastases to resectable tumors, which improved clinical outcomes $[142,143]$. Interestingly, immunotherapy such as CAR-T cell or modified T cell therapy, immune checkpoint inhibitor (ICI), TLR agonist, and Granulocyte-macrophage colony-stimulating factor (GM-CSF) are also being investigated in several clinical trials (Table 1). In addition, other therapies, such as ultrasound mediated local therapy, Vitamin D3, and ATP128 (a self-adjuvanted chimeric recombinant protein vaccine) are under investigation.

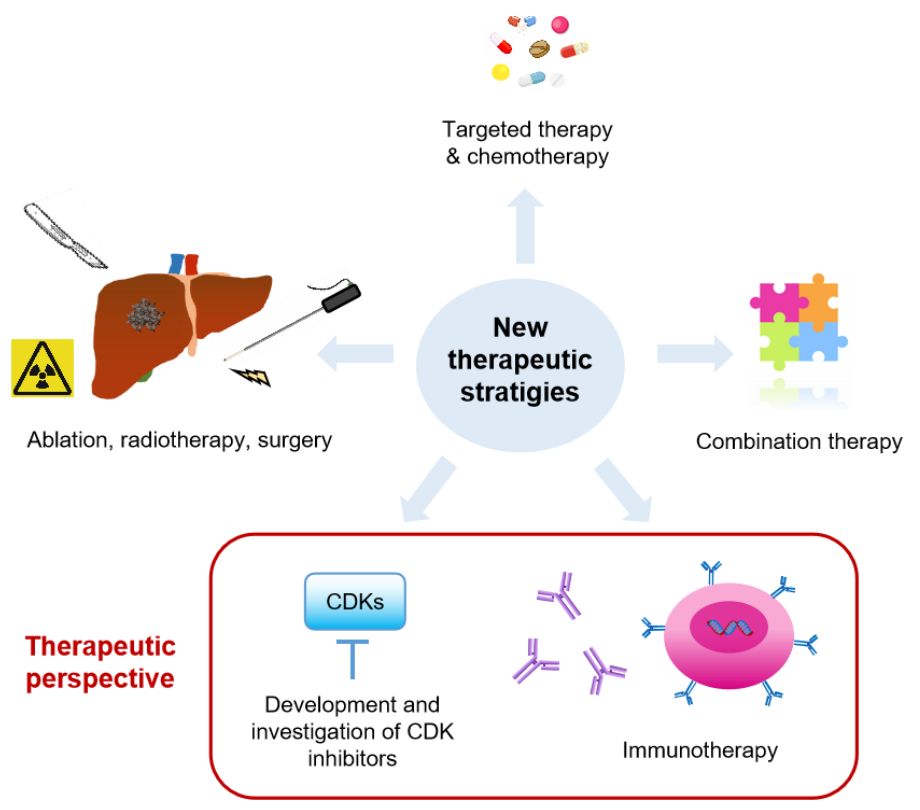

Figure 3. Therapeutic perspectives for colorectal cancer liver metastasis. Several new therapeutic strategies are under clinical trials, including: (1) novel or the combination of targeted therapy and chemotherapy, either locally or systemically; (2) ablation, radiotherapy, surgery; (3) the combination of current therapies; (4) development and investigation of CDK inhibitors; (5) immunotherapy like immune checkpoint inhibitor, CAR-T cells, etc. 
Table 1. Ongoing clinical trials evaluating the use of different modalities in metastatic colorectal cancer.

\begin{tabular}{|c|c|c|c|c|}
\hline Trial ID & Phase & Study Population & Intervention & Recruitment Status \\
\hline \multicolumn{5}{|c|}{ Targeted therapy and chemotherapy (Locally or systemically) } \\
\hline NCT04509635 & III & $\begin{array}{l}\text { Colorectal Cancer Liver Metastasis } \\
\text { with Progression After First-line } \\
\text { Treatment of Cetuximab }\end{array}$ & Cetuximab \pm Chemotherapy & Not yet recruiting \\
\hline NCT03493061 & II & $\begin{array}{c}\text { Unresectable Colorectal Cancer } \\
\text { Liver Metastases }\end{array}$ & $\begin{array}{l}\text { Irinotecan; Oxaliplatin; } \\
\text { Floxuridine }\end{array}$ & Recruiting \\
\hline NCT04189055 & II & $\begin{array}{c}\text { Neo Wild-type RAS/RAF Metastatic } \\
\text { Colorectal Cancer with Liver } \\
\text { Metastases }\end{array}$ & Cetuximab; Irinotecan & Recruiting \\
\hline NCT04276090 & NA & $\begin{array}{l}\text { Unresectable Colorectal } \\
\text { Metastases/Intrahepatic } \\
\text { Cholangiocarcinoma }\end{array}$ & $\begin{array}{c}\text { Codman Catheter; } \\
\text { Synchromed Pump Hepatic } \\
\text { Artery Chemotherapy } \\
\text { Irinotecan Drug-Eluting-Bead }\end{array}$ & Recruiting \\
\hline NCT03697044 & NA & Colorectal Cancer Liver Metastases & $\begin{array}{l}\text { Trans Arterial } \\
\text { ChemoEmbolisation }\end{array}$ & Not yet recruiting \\
\hline $\begin{array}{l}\text { NCT03125161/ } \\
\text { NCT02102789 }\end{array}$ & III & $\begin{array}{l}\text { Unresectable Colorectal Cancer } \\
\text { Liver Metastases }\end{array}$ & $\begin{array}{l}\text { HAI; Chemotherapy } \pm \text { target } \\
\text { therapy or mFOLFOX6 }\end{array}$ & Recruiting \\
\hline NCT04003792 & II & $\begin{array}{c}\text { Unresectable Colorectal Cancer } \\
\text { Liver Metastases }\end{array}$ & $\begin{array}{c}\text { oxaliplatin; FOLFIRI Protocol; } \\
\text { Bevacizumab }\end{array}$ & Recruiting \\
\hline NCT00695201 & $\mathrm{I}$ & $\begin{array}{c}\text { Unresectable Colorectal Cancer } \\
\text { Liver Metastases }\end{array}$ & $\begin{array}{l}\text { Floxuridine, Oxaliplatin, } \\
\text { CPT-11 }\end{array}$ & Active, not recruiting \\
\hline NCT04194034 & $\mathrm{I} / \mathrm{II}$ & $\begin{array}{c}\text { Unresectable Colorectal Cancer } \\
\text { Liver Metastases }\end{array}$ & TG6002; Flucytosine (5-FC) & Recruiting \\
\hline NCT04595266 & II & Colorectal Cancer Liver Metastases & $\begin{array}{c}\text { FOLFOX regimen; Anti-EGFR } \\
\text { or Bevacizumab; } \\
\text { LIVERPEARLS-Irinotecan } \\
\text { Oxaliplatin, Cetuximab }\end{array}$ & Not yet recruiting \\
\hline NCT03164655 & II & $\begin{array}{c}\text { Unresectable Colorectal Cancer } \\
\text { Liver Metastases }\end{array}$ & $\begin{array}{l}\text { Bevacizumab, Panitumumab, } \\
\text { Irinotecan, Leucovorin, } \\
\text { 5-Fluorouracil }\end{array}$ & Recruiting \\
\hline NCT03031444 & II/III & $\begin{array}{c}\text { Resectable Colorectal Liver } \\
\text { Metastasis }\end{array}$ & $\begin{array}{c}\text { Cetuximab plus } \\
\text { FOLFIRI/FOLFOX; } \\
\text { FOLFIRI/FOLFOX/CapeOX }\end{array}$ & Recruiting \\
\hline NCT04525326 & III & $\begin{array}{l}\text { Unresectable Colorectal Cancer } \\
\text { Liver Metastases }\end{array}$ & $\begin{array}{c}\text { Cetuximab; Bevacizumab; } \\
\text { mFOLFOX/FOLFIRI } \\
\text { (Standard Chemotherapy) }\end{array}$ & Not yet recruiting \\
\hline NCT03366155 & II & Colorectal Cancer Liver Metastases & $\begin{array}{l}\text { Panitumumab; FUDR-Dex; } \\
\text { Oxaliplatin; 5FU; Irinotecan; } \\
\text { cetuximab }\end{array}$ & \\
\hline NCT01312857 & II & $\begin{array}{l}\text { Resected Colorectal Cancer Liver } \\
\text { Metastasis with Wild Type RAS }\end{array}$ & panitumumab & Active, not recruiting \\
\hline NCT03732235 & NA & $\begin{array}{c}\text { Refractory Colorectal Cancer Liver } \\
\text { Metastases }\end{array}$ & $\begin{array}{l}\text { TACE+ systemic Bevacizumab; } \\
\text { FOLFIRI+Bevacizumab; TACE }\end{array}$ & Recruiting \\
\hline NCT04126655 & $\mathrm{I} / \mathrm{II}$ & Colorectal Cancer Liver Metastases & $\begin{array}{l}\text { Arfolitixorin + 5-FU; } \\
\text { Calciumfolinate + 5-FU }\end{array}$ & Recruiting \\
\hline NCT03477019 & $\mathrm{I} / \mathrm{II}$ & $\begin{array}{l}\text { Liver Metastasis from Breast- and } \\
\text { Colorectal Cancer }\end{array}$ & SonoVue; Focused Ultrasound & Recruiting \\
\hline NCT03458975 & II & Colorectal Cancer Liver Metastases & $\begin{array}{l}\text { Contrast enhanced ultrasound; } \\
\text { Sonoporation }\end{array}$ & Recruiting \\
\hline NCT04021277 & $\mathrm{I}$ & Colorectal Cancer Liver Metastases & $\begin{array}{c}\text { PS101-mediated Acoustic } \\
\text { Cluster Therapy }\end{array}$ & Recruiting \\
\hline NCT03493048 & II & $\begin{array}{l}\text { RAS wildtype Unresectable } \\
\text { Colorectal Cancer Liver Metastases }\end{array}$ & $\begin{array}{l}\text { Irinotecan; Cetuximab; } \\
\text { 5-fluorouracil; Oxaliplatin; } \\
\text { Leucovorin }\end{array}$ & Recruiting \\
\hline NCT03801915 & II & $\begin{array}{l}\text { Colorectal Cancer Liver Metastases } \\
\text { Stage I-III Colon Cancer or }\end{array}$ & MVT-5873 & Recruiting \\
\hline NCT02172651 & $\begin{array}{c}\text { Early } \\
\text { Phase } 1\end{array}$ & $\begin{array}{c}\text { Resectable Colon Cancer Liver } \\
\text { Metastases }\end{array}$ & Vitamin D3 & Recruiting \\
\hline
\end{tabular}


Table 1. Cont.

\begin{tabular}{|c|c|c|c|c|}
\hline Trial ID & Phase & Study Population & Intervention & Recruitment Status \\
\hline \multicolumn{5}{|c|}{ Ablation, radiotherapy, surgery } \\
\hline NCT03088150 & NAII & Colorectal Cancer Liver Metastases & $\begin{array}{l}\text { Thermal ablation; Surgical } \\
\text { resection }\end{array}$ & Recruiting \\
\hline $\begin{array}{l}\text { NCT03963726/ } \\
\text { NCT03654131/ } \\
\text { NCT04081168 }\end{array}$ & NA/II & Colorectal Cancer Liver Metastases & $\begin{array}{l}\text { stereotactic radiotherapy; } \\
\text { microwave ablation }\end{array}$ & Recruiting \\
\hline NCT02185443 & II & $\begin{array}{c}\text { Unresectable Colorectal Cancer } \\
\text { Liver Metastases }\end{array}$ & SBRT & Recruiting \\
\hline NCT04491929 & NA & $\begin{array}{c}\text { Refractory Colorectal Cancer Liver } \\
\text { Metastases }\end{array}$ & $\begin{array}{l}\text { Selective Internal Radiation } \\
\text { Therapy With 90Y Resin }\end{array}$ & Recruiting \\
\hline NCT03895723 & NA & Colorectal Cancer Liver Metastases & $\begin{array}{l}\text { laparoscopic and robotic liver } \\
\text { resection or open surgery }\end{array}$ & Recruiting \\
\hline NCT02954913 & NA & Colorectal Cancer Liver Metastases & Simultaneous Resection & Recruiting \\
\hline NCT03803436 & II & $\begin{array}{c}\text { Unresectable Colorectal Cancer } \\
\text { Liver Metastases }\end{array}$ & $\begin{array}{l}\text { liver transplantation vs triplet } \\
\text { chemotherapy+antiEGFR }\end{array}$ & Recruiting \\
\hline $\begin{array}{l}\text { NCT02864485/ } \\
\text { NCT01479608/ } \\
\text { NCT02597348 }\end{array}$ & NA; II; III & $\begin{array}{l}\text { Unresectable Colorectal Cancer } \\
\text { Liver Metastases }\end{array}$ & liver transplantation & Recruiting \\
\hline NCT02215889 & $\mathrm{I} / \mathrm{II}$ & Colorectal Cancer Liver Metastases & $\begin{array}{l}\text { Partial Liver Segment 2/3 } \\
\text { Transplantation }\end{array}$ & Recruiting \\
\hline NCT03494946 & NA & Colorectal Cancer Liver Metastases & $\begin{array}{l}\text { Liver transplantation vs } \\
\text { Chemotherapy }\end{array}$ & Recruiting \\
\hline NCT04161092 & NA & $\begin{array}{l}\text { non-resectable/ non-abatable } \\
\text { colorectal liver metastases }\end{array}$ & $\begin{array}{l}\text { Liver transplantation Ltx or } \\
\text { best alternative care }\end{array}$ & Not yet recruiting \\
\hline NCT03488953 & NA & $\begin{array}{c}\text { Isolated, Irresectable Colorectal } \\
\text { Liver Metastases }\end{array}$ & $\begin{array}{l}\text { Living donor liver } \\
\text { transplantation with } \\
\text { two-staged hepatectomy }\end{array}$ & Recruiting \\
\hline NCT03577665 & NA & Colorectal Cancer Liver Metastases & Curative Proton Beam Therapy & Recruiting \\
\hline NCT04108481 & $\mathrm{I} / \mathrm{II}$ & Colorectal Cancer Liver Metastases & $\begin{array}{l}\text { Durvalumab; Yttrium-90 } \\
\text { RadioEmbolization }\end{array}$ & Recruiting \\
\hline \multicolumn{5}{|c|}{ Immunotherapy } \\
\hline NCT02754856 & I & $\begin{array}{c}\text { Resectable Colorectal Cancer Liver } \\
\text { Metastases }\end{array}$ & Durvalumab; Tremelimumab & Recruiting \\
\hline NCT03370198 & I & $\begin{array}{l}\text { Unresectable Liver Metastases from } \\
\text { Colorectal Cancer }\end{array}$ & $\begin{array}{l}\text { Hepatic Transarterial } \\
\text { Administrations of } \\
\text { NKR-2(modified T cells) }\end{array}$ & Active, not recruiting \\
\hline NCT02850536 & I & Liver Metastases or Pancreas Cancer & anti-CEA CAR-T cells & Active, not recruiting \\
\hline NCT04513431 & $\begin{array}{c}\text { Early } \\
\text { Phase } 1\end{array}$ & $\begin{array}{c}\text { Stage III Colorectal Cancer } \\
\text { Colorectal Cancer Liver Metastasis }\end{array}$ & Anti-CEA-CAR T & Not yet recruiting \\
\hline \multicolumn{5}{|c|}{ Combination therapy } \\
\hline NCT04062721 & $\mathrm{Ib} / \mathrm{II}$ & $\begin{array}{c}\text { Unresectable Colorectal Liver } \\
\text { Metastases }\end{array}$ & $\begin{array}{c}\text { radiofrequency ablation (RFA) } \\
\text { plus in situ TLR agonist and } \\
\text { GM-CSF }\end{array}$ & Not yet recruiting \\
\hline NCT04202978 & $\mathrm{I} / \mathrm{II}$ & Colorectal Cancer Liver Metastases & $\begin{array}{c}\text { Camrelizumab Combined } \\
\text { With Apatinib XELOX RFA }\end{array}$ & Recruiting \\
\hline NCT03223779 & $\mathrm{I} / \mathrm{II}$ & Colorectal Cancer Liver Metastases & TAS-102; Photon SBRT & Recruiting \\
\hline NCT02738606 & II & $\begin{array}{l}\text { Resectable Colorectal Cancer Liver } \\
\text { Metastases and unresectable } \\
\text { Colorectal Cancer Lung Metastases }\end{array}$ & $\begin{array}{l}\text { liver surgery and } \\
\text { chemotherapy }\end{array}$ & Recruiting \\
\hline NCT03127072 & IV & $\begin{array}{l}\text { Unresectable Colorectal Cancer } \\
\text { Liver Metastases }\end{array}$ & $\begin{array}{c}\text { Radiofrequency Ablation } \\
\text { (RFA); chemotherapy } \pm \text { target } \\
\text { therapy }\end{array}$ & Recruiting \\
\hline
\end{tabular}


Table 1. Cont.

\begin{tabular}{|c|c|c|c|c|}
\hline Trial ID & Phase & Study Population & Intervention & Recruitment Status \\
\hline \multicolumn{5}{|c|}{ Combination therapy } \\
\hline NCT04562727 & NA/II & Colorectal Cancer Liver Metastases & $\begin{array}{c}\text { Microwave Ablation } \\
\text { Combined with Chemotherapy }\end{array}$ & Not yet recruiting \\
\hline NCT03135652 & II & $\begin{array}{c}\text { Colorectal Cancer Liver Metastases } \\
\text { Receiving Surgery or } \\
\text { Radiofrequency Ablation }\end{array}$ & $\begin{array}{l}\text { Adjuvant SBRT; } \\
\text { Chemotherapy }\end{array}$ & Recruiting \\
\hline NCT03101475 & II & Colorectal Cancer Liver Metastases & $\begin{array}{c}\text { Durvalumab (MEDI4736); } \\
\text { Tremelimumab; Sterotactic } \\
\text { body radiation therapy (SBRT); } \\
\text { Radiofrequency ablation (RFA) }\end{array}$ & Recruiting \\
\hline NCT04508140 & II & $\begin{array}{c}\text { Colorectal or Gastric/GEJ Cancer } \\
\text { with Liver Metastasis }\end{array}$ & BO-112 with Pembrolizumab & Recruiting \\
\hline NCT03507699 & $\mathrm{I}$ & Colorectal Cancer Liver Metastases & $\begin{array}{l}\text { Liver radiation therapy; } \\
\text { Nivolumab Injection; } \\
\text { Ipilimumab Injection; } \\
\text { CMP-001 }\end{array}$ & Recruiting \\
\hline NCT04166383 & II & Colorectal Cancer Liver Metastases & VB-111; Nivolumab & Recruiting \\
\hline NCT03785210 & II & $\begin{array}{l}\text { Refractory Primary Hepatocellular } \\
\text { Carcinoma or Liver Dominant } \\
\text { Metastatic Cancer from Colorectal or } \\
\text { Pancreatic Cancers }\end{array}$ & $\begin{array}{l}\text { nivolumab; tadalafil; oral } \\
\text { vancomycin }\end{array}$ & Recruiting \\
\hline NCT04430985 & II & Colorectal Cancer Liver Metastases & $\begin{array}{l}\text { Oxaliplatin; 5-Fluorouracil; } \\
\text { Leucovorin; Nivolumab; } \\
\text { Ipilimumab }\end{array}$ & Recruiting \\
\hline NCT03698461 & II & Colorectal Cancer Liver Metastases & $\begin{array}{c}\text { Atezolizumab; Bevacizumab; } \\
\text { Oxaliplatin; Levoleucovorin; } \\
\text { 5-FU }\end{array}$ & Recruiting \\
\hline NCT03310008 & I & $\begin{array}{l}\text { Colorectal Cancer with Potentially } \\
\text { Resectable Liver Metastases }\end{array}$ & $\begin{array}{l}\text { NKR-2(modified T cells) with } \\
\text { FOLFOX }\end{array}$ & Active, not recruiting \\
\hline NCT04046445 & $\mathrm{I} / \mathrm{II}$ & Stage IV Colorectal Cancer & ATP128; BI 754091 & Recruiting \\
\hline
\end{tabular}

\section{Conclusions}

In this review, we emphasized on the critical role of the premetastatic niche in the liver microenvironment in facilitating cancer liver metastasis. The disseminating tumor cells depend on interaction with the liver immune microenvironment for arrest, immune evasion, colonization, migration, and proliferation. Thus, a better understanding of the molecular mechanisms orchestrating the formation of a hospitable hepatic metastatic niche and the identification of the drivers supporting this process is critical for the development of better therapies to stop or at least decrease liver metastasis. Besides, the anatomic proximity between liver and colon as well as specific signals derived from CRC cells may partially explain the clinical preference of CRC liver metastasis. Nevertheless, CRC liver metastasis may also share similar mechanisms with the liver tropism of different cancer metastasis via the regulations of liver immune microenvironment, as we summarized here. Therefore, mechanistic insights on CRC liver metastasis may also pave ways to new perspectives in liver metastasis from other cancer types.

Traditional chemotherapy, surgical resection, and localized therapy still dominate the treatment for CRC liver metastasis. Although these therapies can remove or control the metastatic tumors, recurrence remains the major challenge for successful management of the disease. Immunotherapy is characterized by strong and long-lasting effects with fewer side effects. Based on the importance of hepatic niche in every step of liver metastasis, targeting the immune microenvironment by immunotherapy will be potential in treating CRC liver metastasis. Future studies should use preclinical models or single cell sequencing 
to investigate the complex immune crosstalk in the liver microenvironment to identify the potential target and translate to the clinics.

Author Contributions: Conceptualization, A.S.L.C., J.Z. and X.Z.; writing-original draft preparation, X.Z.; writing-review and editing, A.S.L.C., J.Z., S.E.W. and X.Z.; supervision, A.S.L.C. and J.Z. All authors have read and agreed to the published version of the manuscript.

Funding: This research was funded by National Natural Science Foundation of China, Research Fund for Young Scholar (82003105); Research Grants Council of Hong Kong, Collaborative Research Fund (C4045-18W), General Research Fund (14108219, 14104820); and the Li Ka Shing Foundation.

Conflicts of Interest: The authors declare no conflict of interest.

\section{References}

1. Chaffer, C.L.; Weinberg, R.A. A Perspective on Cancer Cell Metastasis. Science 2011, 331, 1559-1564. [CrossRef] [PubMed]

2. Budczies, J.; Von Winterfeld, M.; Klauschen, F.; Bockmayr, M.; Lennerz, J.K.; Denkert, C.; Wolf, T.; Warth, A.; Dietel, M.; Anagnostopoulos, I.; et al. The landscape of metastatic progression patterns across major human cancers. Oncotarget 2014, 6, 570-583. [CrossRef]

3. Mielgo, A.; Schmid, M.C. Liver Tropism in Cancer: The Hepatic Metastatic Niche. Cold Spring Harb. Perspect. Med. 2019, 10, a037259. [CrossRef]

4. Ciner, A.T.; Jones, K.; Muschel, R.J.; Brodt, P. The unique immune microenvironment of liver metastases: Challenges and opportunities. Semin. Cancer Biol. 2021, 71, 143-156. [CrossRef]

5. de Ridder, J.; de Wilt, J.H.; Simmer, F.; Overbeek, L.; Lemmens, V.; Nagtegaal, I. Incidence and origin of histologically confirmed liver metastases: An explorative case-study of 23,154 patients. Oncotarget 2016, 7, 55368-55376. [CrossRef] [PubMed]

6. Rawla, P.; Sunkara, T.; Barsouk, A. Epidemiology of colorectal cancer: Incidence, mortality, survival, and risk factors. Gastroenterol. Rev. 2019, 14, 89-103. [CrossRef]

7. Millikan, K.W.; Staren, E.D.; Doolas, A. Invasive Therapy of Metastatic colorectal cancer to the liver. Surg. Clin. N. Am. 1997, 77, 27-48. [CrossRef]

8. Alberts, S.R.; Wagman, L.D. Chemotherapy for Colorectal Cancer Liver Metastases. Oncologist 2008, 13, 1063-1073. [CrossRef] [PubMed]

9. Konopke, R.; Kersting, S.; Distler, M.; Dietrich, J.; Gastmeier, J.; Heller, A.; Kulisch, E.; Saeger, H.-D. Prognostic factors and evaluation of a clinical score for predicting survival after resection of colorectal liver metastases. Liver Int. 2009, $29,89-102$. [CrossRef] [PubMed]

10. Jemal, A.; Murray, T.; Ward, E.; Samuels, A.; Tiwari, R.C.; Ghafoor, A.; Feuer, E.J.; Thun, M.J. Cancer Statistics, 2005. CA Cancer J. Clin. 2005, 55, 10-30. [CrossRef] [PubMed]

11. Galjart, B.; Nierop, P.M.H.; Van Der Stok, E.P.; Braak, R.R.J.C.V.D.; Höppener, D.J.; Daelemans, S.; Dirix, L.Y.; Verhoef, C.; Vermeulen, P.B.; Grünhagen, D.J. Angiogenic desmoplastic histopathological growth pattern as a prognostic marker of good outcome in patients with colorectal liver metastases. Angiogenesis 2019, 22, 355-368. [CrossRef] [PubMed]

12. Garcia-Vicien, G.; Mezheyeuski, A.; Banuls, M.; Ruiz-Roig, N.; Mollevi, D.G. The Tumor Microenvironment in Liver Metastases from Colorectal Carcinoma in the Context of the Histologic Growth Patterns. Int. J. Mol. Sci. 2021, 22, 1544. [CrossRef]

13. Höppener, D.J.; Nierop, P.M.H.; Hof, J.; Sideras, K.; Zhou, G.; Visser, L.; Gouw, A.S.H.; De Jong, K.P.; Sprengers, D.; Kwekkeboom, J.; et al. Enrichment of the tumour immune microenvironment in patients with desmoplastic colorectal liver metastasis. Br. J. Cancer 2020, 123, 196-206. [CrossRef]

14. Brunner, S.M.; Kesselring, R.; Rubner, C.; Martin, M.; Jeiter, T.; Boerner, T.; Ruemmele, P.; Schlitt, H.J.; Fichtner-Feigl, S. Prognosis according to histochemical analysis of liver metastases removed at liver resection. Br. J. Surg. 2014, 101, 1681-1691. [CrossRef] [PubMed]

15. van Dam, P.-J.; Daelemans, S.; Ross, E.; Waumans, Y.; Van Laere, S.; Latacz, E.; Van Steen, R.; De Pooter, C.; Kockx, M.; Dirix, L.; et al. Histopathological growth patterns as a candidate biomarker for immunomodulatory therapy. Semin. Cancer Biol. 2018, 52, 86-93. [CrossRef]

16. van Dam, P.-J.; van der Stok, E.P.; Teuwen, L.A.; Van den Eynden, G.G.; Illemann, M.; Frentzas, S.; Majeed, A.W.; Eefsen, R.L.; Coebergh van den Braak, R.R.J.; Lazaris, A.; et al. International consensus guidelines for scoring the histopathological growth patterns of liver metastasis. Br. J. Cancer. 2017, 117, 1427-1441. [CrossRef] [PubMed]

17. Nielsen, K.; Rolff, H.C.; Eefsen, R.L.; Vainer, B. The morphological growth patterns of colorectal liver metastases are prognostic for overall survival. Mod. Pathol. 2014, 27, 1641-1648. [CrossRef]

18. Stremitzer, S.; Vermeulen, P.; Graver, S.; Kockx, M.; Dirix, L.; Yang, D.; Zhang, W.; Stift, J.; Wrba, F.; Gruenberger, T.; et al. Immune phenotype and histopathological growth pattern in patients with colorectal liver metastases. Br. J. Cancer. 2020, 122, 1518-1524. [CrossRef]

19. Rees, M.; Tekkis, P.P.; Welsh, F.K.; O'Rourke, T.; John, T.G. Evaluation of long-term survival after hepatic resection for metastatic colorectal cancer: A multifactorial model of 929 patients. Ann. Surg. 2008, 247, 125-135. [CrossRef] 
20. Nordlinger, B.; Guiguet, M.; Vaillant, J.C.; Balladur, P.; Boudjema, K.; Bachellier, P.; Jaeck, D. Surgical resection of colorectal carcinoma metastases to the liver. A prognostic scoring system to improve case selection, based on 1568 patients. Association Française de Chirurgie. Cancer 1996, 77, 1254-1262. [CrossRef]

21. Hurwitz, H.; Fehrenbacher, L.; Novotny, W.; Cartwright, T.; Hainsworth, J.; Heim, W.; Berlin, J.; Baron, A.; Griffing, S.; Holmgren, E.; et al. Bevacizumab plus Irinotecan, Fluorouracil, and Leucovorin for Metastatic Colorectal Cancer. N. Engl. J. Med. 2004, 350, 2335-2342. [CrossRef] [PubMed]

22. Maiello, E.; Giuliani, F.; Gebbia, V.; Piano, A.; Agueli, R.; Colucci, G. Cetuximab: Clinical results in colorectal cancer. Ann. Oncol. 2007, 18, vi8-vi10. [CrossRef]

23. Kim, J.H.; Kim, S.Y.; Baek, J.Y.; Cha, Y.J.; Ahn, J.B.; Kim, H.S.; Lee, K.W.; Kim, J.W.; Kim, T.Y.; Chang, W.J.; et al. A Phase II Study of Avelumab Monotherapy in Patients with Mismatch Repair-Deficient/Microsatellite Instability-High or POLE-Mutated Metastatic or Unresectable Colorectal Cancer. Cancer Res. Treat. 2020, 52, 1135-1144. [CrossRef] [PubMed]

24. Zhang, C.; Wang, Z.; Yang, Z.; Wang, M.; Li, S.; Li, Y.; Zhang, R.; Xiong, Z.; Wei, Z.; Shen, J.; et al. Phase I Escalating-Dose Trial of CAR-T Therapy Targeting CEA + Metastatic Colorectal Cancers. Mol. Ther. 2017, 25, 1248-1258. [CrossRef]

25. Lambert, A.W.; Pattabiraman, D.R.; Weinberg, R.A. Emerging Biological Principles of Metastasis. Cell 2017, 168, 670-691. [CrossRef] [PubMed]

26. Armaghany, T.; Wilson, J.D.; Chu, Q.; Mills, G. Genetic Alterations in Colorectal Cancer. Gastrointest. Cancer Res. $2012,5,19-27$.

27. Mantovani, A.; Allavena, P.; Sica, A.; Balkwill, F.R. Cancer-related inflammation. Nat. Cell Biol. 2008, 454, 436-444. [CrossRef]

28. Kitamura, T.; Qian, B.-Z.; Pollard, J.W. Immune cell promotion of metastasis. Nat. Rev. Immunol. 2015, 15, 73-86. [CrossRef]

29. Joyce, J.A.; Pollard, J.W. Microenvironmental regulation of metastasis. Nat. Rev. Cancer 2008, 9, 239-252. [CrossRef] [PubMed]

30. Vidal-Vanaclocha, F.; Crende, O.; de Durango, C.G.; Herreros-Pomares, A.; López-Doménech, S.; González, Á.; Ruiz-Casares, E.; Vilboux, T.; Caruso, R.; Durán, H.; et al. Liver prometastatic reaction: Stimulating factors and responsive cancer phenotypes. Semin. Cancer Biol. 2021, 71, 122-133. [CrossRef]

31. Costa-Silva, B.; Aiello, N.M.; Ocean, A.J.; Singh, S.; Zhang, H.; Thakur, B.K.; Becker, A.; Hoshino, A.; Mark, M.T.; Molina, H.; et al. Pancreatic cancer exosomes initiate pre-metastatic niche formation in the liver. Nat. Cell Biol. 2015, 17, 816-826. [CrossRef] [PubMed]

32. Psaila, B.; Lyden, D. The metastatic niche: Adapting the foreign soil. Nat. Rev. Cancer 2009, 9, 285-293. [CrossRef]

33. Thomas, H. IL-6 drives niche formation in pancreatic cancer liver metastasis. Nat. Rev. Gastroenterol. Hepatol. 2019, 16, 263. [CrossRef]

34. Mohr, A.M.; Gould, J.J.; Kubik, J.L.; Talmon, G.A.; Casey, C.A.; Thomas, P.; Tuma, D.J.; McVicker, B.L. Enhanced colorectal cancer metastases in the alcohol-injured liver. Clin. Exp. Metastasis 2017, 34, 171-184. [CrossRef]

35. Wang, N.; Rayes, R.F.; Elahi, S.M.; Lu, Y.; Hancock, M.A.; Massie, B.; Rowe, G.E.; Aomari, H.; Hossain, S.; Durocher, Y.; et al. The IGF-Trap: Novel Inhibitor of Carcinoma Growth and Metastasis. Mol. Cancer Ther. 2015, 14, 982-993. [CrossRef] [PubMed]

36. Wagh, P.K.; Peace, B.E.; Waltz, S.E. Met-Related Receptor Tyrosine Kinase Ron in Tumor Growth and Metastasis. Adv. Cancer Res. 2008, 100, 1-33. [CrossRef] [PubMed]

37. Yoshioka, T.; Nishikawa, Y.; Ito, R.; Kawamata, M.; Doi, Y.; Yamamoto, Y.; Yoshida, M.; Omori, Y.; Kotanagi, H.; Masuko, T.; et al. Significance of integrin alphavbeta5 and erbB3 in enhanced cell migration and liver metastasis of colon carcinomas stimulated by hepatocyte-derived heregulin. Cancer Sci. 2010, 101, 2011-2018. [CrossRef] [PubMed]

38. Vidal-Vanaclocha, F. The Liver Prometastatic Reaction of Cancer Patients: Implications for Microenvironment-Dependent Colon Cancer Gene Regulation. Cancer Microenviron. 2011, 4, 163-180. [CrossRef]

39. Malumbres, M. Cyclin-dependent kinases. Genome Biol. 2014, 15, 122. [CrossRef]

40. Raycheva, J.; Karanikolova, T.; Krusteva, R.; Taushanova-Hadjieva, M. Efficacy of CDK4/6 Inhibitor in Treatment of Metastatic Breast Cancer and Colon Cancer. Int. J. Clin. Oncol. Cancer Res. 2020, 5, 1-4. [CrossRef]

41. Liang, J.; Chen, M.; Hughes, D.; Chumanevich, A.A.; Altilia, S.; Kaza, V.; Lim, C.U.; Kiaris, H.; Mythreye, K.; Pena, M.M.; et al. CDK8 Selectively Promotes the Growth of Colon Cancer Metastases in the Liver by Regulating Gene Expression of TIMP3 and Matrix Metalloproteinases. Cancer Res. 2018, 78, 6594-6606. [CrossRef] [PubMed]

42. Duarte, S.; Baber, J.; Fujii, T.; Coito, A.J. Matrix metalloproteinases in liver injury, repair and fibrosis. Matrix Biol. 2015, 44-46, 147-156. [CrossRef] [PubMed]

43. Zeng, X.; Zhou, J.; Xiong, Z.; Sun, H.; Yang, W.; Mok, M.T.S.; Wang, J.; Li, J.; Liu, M.; Tang, W.; et al. Cell cycle-related kinase reprograms the liver immune microenvironment to promote cancer metastasis. Cell. Mol. Immunol. 2020, 18, 1005-1015. [CrossRef]

44. Tsuchida, T.; Friedman, S.L. Mechanisms of hepatic stellate cell activation. Nat. Rev. Gastroenterol. Hepatol. 2017, 14, 397-411. [CrossRef] [PubMed]

45. Liu, M.; Zhou, J.; Liu, X.; Feng, Y.; Yang, W.; Wu, F.; Cheung, O.K.-W.; Sun, H.; Zeng, X.; Tang, W.; et al. Targeting monocyteintrinsic enhancer reprogramming improves immunotherapy efficacy in hepatocellular carcinoma. Gut 2020, 69, 365-379. [CrossRef]

46. Bao, S.; Ouyang, G.; Bai, X.; Huang, Z.; Ma, C.; Liu, M.; Shao, R.; Anderson, R.M.; Rich, J.N.; Wang, X.-F. Periostin potently promotes metastatic growth of colon cancer by augmenting cell survival via the Akt/PKB pathway. Cancer Cell 2004, 5, 329-339. [CrossRef]

47. Eveno, C.; Hainaud, P.; Rampanou, A.; Bonnin, P.; Bakhouche, S.; Dupuy, E.; Contreres, J.O.; Pocard, M. Proof of prometastatic niche induction by hepatic stellate cells. J. Surg. Res. 2015, 194, 496-504. [CrossRef] 
48. Takatsuna, M.; Morohashi, S.; Yoshizawa, T.; Hirai, H.; Haga, T.; Ota, R.; Wu, Y.; Morohashi, H.; Hakamada, K.; Terai, S.; et al. Myofibroblasts of the muscle layer stimulate the malignant potential of colorectal cancer. Oncol. Rep. 2016, 36, $1251-1257$. [CrossRef]

49. Solano-Iturri, J.D.; Beitia, M.; Errarte, P.; Calvete-Candenas, J.; Etxezarraga, M.C.; Loizate, A.; Echevarria, E.; Badiola, I.; Larrinaga, G. Altered expression of fibroblast activation protein-alpha (FAP) in colorectal adenoma-carcinoma sequence and in lymph node and liver metastases. Aging 2020, 12, 10337-10358. [CrossRef]

50. Zhang, R.; Qi, F.; Shao, S.; Li, G.; Feng, Y. Human colorectal cancer-derived carcinoma associated fibroblasts promote CD44mediated adhesion of colorectal cancer cells to endothelial cells by secretion of HGF. Cancer Cell Int. 2019, 19, 192. [CrossRef]

51. Gonzalez-Zubeldia, I.; Dotor, J.; Redrado, M.; Bleau, A.M.; Manrique, I.; de Aberasturi, A.L.; Villalba, M.; Calvo, A. Co-migration of colon cancer cells and CAFs induced by TGFbeta (1) enhances liver metastasis. Cell Tissue Res. 2015, 359, 829-839. [CrossRef]

52. Hu, J.L.; Wang, W.; Lan, X.L.; Zeng, Z.C.; Liang, Y.S.; Yan, Y.R.; Song, F.Y.; Wang, F.F.; Zhu, X.H.; Liao, W.J.; et al. CAFs secreted exosomes promote metastasis and chemotherapy resistance by enhancing cell stemness and epithelial-mesenchymal transition in colorectal cancer. Mol. Cancer 2019, 18, 91. [CrossRef] [PubMed]

53. Tan, H.X.; Gong, W.Z.; Zhou, K.; Xiao, Z.G.; Hou, F.T.; Huang, T.; Zhang, L.; Dong, H.Y.; Zhang, W.L.; Liu, Y.; et al. CXCR4/TGFbeta1 mediated hepatic stellate cells differentiation into carcinoma-associated fibroblasts and promoted liver metastasis of colon cancer. Cancer Biol. Ther. 2020, 21, 258-268. [CrossRef] [PubMed]

54. Abdul-Wahid, A.; Cydzik, M.; Fischer, N.W.; Prodeus, A.; Shively, J.E.; Martel, A.; Alminawi, S.; Ghorab, Z.; Berinstein, N.L.; Gariepy, J. Serum-derived carcinoembryonic antigen (CEA) activates fibroblasts to induce a local re-modeling of the extracellular matrix that favors the engraftment of CEA-expressing tumor cells. Int. J. Cancer 2018, 143, 1963-1977. [CrossRef]

55. Ouahoud, S.; Voorneveld, P.W.; van der Burg, L.R.A.; de Jonge-Muller, E.S.M.; Schoonderwoerd, M.J.A.; Paauwe, M.; de Vos, T.; de Wit, S.; van Pelt, G.W.; Mesker, W.E.; et al. Bidirectional tumor/stroma crosstalk promotes metastasis in mesenchymal colorectal cancer. Oncogene 2020, 39, 2453-2466. [CrossRef]

56. Kobayashi, H.; Gieniec, K.A.; Wright, J.A.; Wang, T.; Asai, N.; Mizutani, Y.; Lida, T.; Ando, R.; Suzuki, N.; Lannagan, T.R.; et al. The Balance of Stromal BMP Signaling Mediated by GREM1 and ISLR Drives Colorectal Carcinogenesis. Gastroenterology 2021, 160, 1224-1239.e30. [CrossRef] [PubMed]

57. Shetty, S.; Lalor, P.F.; Adams, D.H. Liver sinusoidal endothelial cells—gatekeepers of hepatic immunity. Nat. Rev. Gastroenterol. Hepatol. 2018, 15, 555-567. [CrossRef]

58. Heymann, F.; Tacke, F. Immunology in the liver-from homeostasis to disease. Nat. Rev. Gastroenterol. Hepatol. 2016, 13, 88-110. [CrossRef]

59. Benedicto, A.; Marquez, J.; Herrero, A.; Olaso, E.; Kolaczkowska, E.; Arteta, B. Decreased expression of the beta2 integrin on tumor cells is associated with a reduction in liver metastasis of colorectal cancer in mice. BMC Cancer 2017, 17, 827. [CrossRef] [PubMed]

60. Khatib, A.-M.; Fallavollita, L.; Wancewicz, E.V.; Monia, B.P.; Brodt, P. Inhibition of hepatic endothelial E-selectin expression by C-raf antisense oligonucleotides blocks colorectal carcinoma liver metastasis. Cancer Res. 2002, 62, 5393-5398.

61. Khatib, A.-M.; Auguste, P.; Fallavollita, L.; Wang, N.; Samani, A.; Kontogiannea, M.; Meterissian, S.; Brodt, P. Characterization of the Host Proinflammatory Response to Tumor Cells during the Initial Stages of Liver Metastasis. Am. J. Pathol. 2005, 167, 749-759. [CrossRef]

62. Ham, B.; Wang, N.; D’Costa, Z.; Fernandez, M.C.; Bourdeau, F.; Auguste, P.; Illemann, M.; Eefsen, R.L.; Høyer-Hansen, G.; Vainer, B.; et al. TNF Receptor-2 Facilitates an Immunosuppressive Microenvironment in the Liver to Promote the Colonization and Growth of Hepatic Metastases. Cancer Res. 2015, 75, 5235-5247. [CrossRef]

63. Wohlfeil, S.A.; Häfele, V.; Dietsch, B.; Schledzewski, K.; Winkler, M.; Zierow, J.; Leibing, T.; Mohammadi, M.M.; Heineke, J.; Sticht, C.; et al. Hepatic Endothelial Notch Activation Protects against Liver Metastasis by Regulating Endothelial-Tumor Cell Adhesion Independent of Angiocrine Signaling. Cancer Res. 2019, 79, 598-610. [CrossRef]

64. Witz, I.P. The selectin-selectin ligand axis in tumor progression. Cancer Metastasis Rev. 2008, 27, 19-30. [CrossRef]

65. Elliott, V.A.; Rychahou, P.; Zaytseva, Y.Y.; Evers, B.M. Activation of c-Met and upregulation of CD44 expression are associated with the metastatic phenotype in the colorectal cancer liver metastasis model. PLoS ONE 2014, 9, e97432. [CrossRef] [PubMed]

66. Aychek, T.; Miller, K.; Sagi-Assif, O.; Levy-Nissenbaum, O.; Israeli-Amit, M.; Pasmanik-Chor, M.; Jacob-Hirsch, J.; Amariglio, N.; Rechavi, G.; Witz, I.P. E-selectin regulates gene expression in metastatic colorectal carcinoma cells and enhances HMGB1 release. Int. J. Cancer 2008, 123, 1741-1750. [CrossRef]

67. Ou, J.; Peng, Y.; Deng, J.; Miao, H.; Zhou, J.; Zha, L.; Zhou, R.; Yu, L.; Shi, H.; Liang, H. Endothelial cell-derived fibronectin extra domain A promotes colorectal cancer metastasis via inducing epithelial-mesenchymal transition. Carcinogenesis 2014, 35, 1661-1670. [CrossRef]

68. Gardner, C.R.; Wasserman, A.J.; Laskin, D.L. Liver macrophage-mediated cytotoxicity toward mastocytoma cells involves phagocytosis of tumor targets. Hepatology 1991, 14, 318-324. [CrossRef] [PubMed]

69. Seki, S.; Nakashima, H.; Nakashima, M.; Kinoshita, M. Antitumor Immunity Produced by the Liver Kupffer Cells, NK Cells, NKT Cells, and CD8+CD122+T Cells. Clin. Dev. Immunol. 2011, 2011, 1-11. [CrossRef]

70. Wang, H.H.; McIntosh, A.R.; Hasinoff, B.B.; Rector, E.S.; Ahmed, N.; Nance, D.M.; Orr, F.W. B16 melanoma cell arrest in the mouse liver induces nitric oxide release and sinusoidal cytotoxicity: A natural hepatic defense against metastasis. Cancer Res. 2000, 60, 5862-5869. [PubMed] 
71. Bayon, L.G.; Izquierdo, M.A.; Sirovich, I.; van Rooijen, N.; Beelen, R.H.; Meijer, S. Role of Kupffer cells in arresting circulating tumor cells and controlling metastatic growth in the liver. Hepatology 1996, 23, 1224-1231. [CrossRef]

72. Heymann, F.; Peusquens, J.; Ludwig-Portugall, I.; Kohlhepp, M.; Ergen, C.; Niemietz, P.; Martin, C.; Van Rooijen, N.; Ochando, J.C.; Randolph, G.J.; et al. Liver inflammation abrogates immunological tolerance induced by Kupffer cells. Hepatology 2015, 62, 279-291. [CrossRef] [PubMed]

73. Fridlender, Z.G.; Sun, J.; Kim, S.; Kapoor, V.; Cheng, G.; Ling, L.; Worthen, G.S.; Albelda, S.M. Polarization of tumor-associated neutrophil phenotype by TGF-beta: “N1" versus “N2" TAN. Cancer Cell 2009, 16, 183-194. [CrossRef] [PubMed]

74. Shaul, M.E.; Fridlender, Z.G. Neutrophils as active regulators of the immune system in the tumor microenvironment. J. Leukoc. Biol. 2017, 102, 343-349. [CrossRef] [PubMed]

75. Seubert, B.; Grünwald, B.; Kobuch, J.; Cui, H.; Schelter, F.; Schaten, S.; Siveke, J.T.; Lim, N.H.; Nagase, H.; Simonavicius, N.; et al. Tissue inhibitor of metalloproteinases (TIMP)-1 creates a premetastatic niche in the liver through SDF-1/CXCR4-dependent neutrophil recruitment in mice. Hepatology 2015, 61, 238-248. [CrossRef] [PubMed]

76. Palmieri, V.; Lazaris, A.; Mayer, T.Z.; Petrillo, S.K.; Alamri, H.; Rada, M.; Jarrouj, G.; Park, W.; Gao, Z.; McDonald, P.P.; et al. Neutrophils expressing lysyl oxidase-like 4 protein are present in colorectal cancer liver metastases resistant to anti-angiogenic therapy. J. Pathol. 2020, 251, 213-223. [CrossRef]

77. Wang, D.; Sun, H.; Wei, J.; Cen, B.; Dubois, R.N. CXCL1 Is Critical for Premetastatic Niche Formation and Metastasis in Colorectal Cancer. Cancer Res. 2017, 77, 3655-3665. [CrossRef]

78. Zhang, Y.; Davis, C.; Ryan, J.; Janney, C.; Pena, M.M. Development and characterization of a reliable mouse model of colorectal cancer metastasis to the liver. Clin. Exp. Metastasis 2013, 30, 903-918. [CrossRef]

79. Diaz-Montero, C.M.; Salem, M.L.; Nishimura, M.I.; Garrett-Mayer, E.; Cole, D.J.; Montero, A.J. Increased circulating myeloidderived suppressor cells correlate with clinical cancer stage, metastatic tumor burden, and doxorubicin-cyclophosphamide chemotherapy. Cancer Immunol. Immunother 2009, 58, 49-59. [CrossRef]

80. Spicer, J.D.; McDonald, B.; Cools-Lartigue, J.J.; Chow, S.C.; Giannias, B.; Kubes, P.; Ferri, L.E. Neutrophils promote liver metastasis via Mac-1-mediated interactions with circulating tumor cells. Cancer Res. 2012, 72, 3919-3927. [CrossRef]

81. Qian, B.Z.; Li, J.; Zhang, H.; Kitamura, T.; Zhang, J.; Campion, L.R.; Kaiser, E.A.; Snyder, L.A.; Pollard, J.W. CCL2 recruits inflammatory monocytes to facilitate breast-tumour metastasis. Nature 2011, 475, 222-225. [CrossRef]

82. Nielsen, S.R.; Quaranta, V.; Linford, A.; Emeagi, P.; Rainer, C.; Santos, A.; Ireland, L.; Sakai, T.; Sakai, K.; Kim, Y.S.; et al. Macrophage-secreted granulin supports pancreatic cancer metastasis by inducing liver fibrosis. Nat. Cell. Biol. 2016, 18, 549-560. [CrossRef]

83. Quaranta, V.; Rainer, C.; Nielsen, S.R.; Raymant, M.L.; Ahmed, M.S.; Engle, D.D.; Taylor, A.; Murray, T.; Campbell, F.; Palmer, D.H.; et al. Macrophage-Derived Granulin Drives Resistance to Immune Checkpoint Inhibition in Metastatic Pancreatic Cancer. Cancer Res. 2018, 78, 4253-4269. [CrossRef]

84. Mitchem, J.B.; Brennan, D.J.; Knolhoff, B.L.; Belt, B.A.; Zhu, Y.; Sanford, D.E.; Belaygorod, L.; Carpenter, D.; Collins, L.; PiwnicaWorms, D.; et al. Targeting tumor-infiltrating macrophages decreases tumor-initiating cells, relieves immunosuppression, and improves chemotherapeutic responses. Cancer Res. 2013, 73, 1128-1141. [CrossRef] [PubMed]

85. Zhao, L.; Lim, S.Y.; Gordon-Weeks, A.N.; Tapmeier, T.T.; Im, J.H.; Cao, Y.; Beech, J.; Allen, D.; Smart, S.; Muschel, R.J. Recruitment of a myeloid cell subset (CD11b/Gr1 mid) via CCL2/CCR2 promotes the development of colorectal cancer liver metastasis. Hepatology 2013, 57, 829-839. [CrossRef] [PubMed]

86. Li, M.; Lai, X.; Zhao, Y.; Zhang, Y.; Li, M.; Li, D.; Kong, J.; Zhang, Y.; Jing, P.; Li, H.; et al. Loss of NDRG2 in liver microenvironment inhibits cancer liver metastasis by regulating tumor associate macrophages polarization. Cell Death Dis. 2018, 9, 1-14. [CrossRef]

87. Robinson, M.W.; Harmon, C.; O'Farrelly, C. Liver immunology and its role in inflammation and homeostasis. Cell. Mol. Immunol. 2016, 13, 267-276. [CrossRef]

88. Wang, F.; Lau, J.K.C.; Yu, J. The role of natural killer cell in gastrointestinal cancer: Killer or helper. Oncogene 2021, 40, 717-730. [CrossRef] [PubMed]

89. Vivier, E.; Tomasello, E.; Baratin, M.; Walzer, T.; Ugolini, S. Functions of natural killer cells. Nat. Immunol. 2008, 9, 503-510. [CrossRef] [PubMed]

90. López-Soto, A.; Gonzalez, S.; Smyth, M.J.; Galluzzi, L. Control of Metastasis by NK Cells. Cancer Cell 2017, 32, 135-154. [CrossRef]

91. Ducimetière, L.; Lucchiari, G.; Litscher, G.; Nater, M.; Heeb, L.; Nuñez, N.G.; Wyss, L.; Burri, D.; Vermeer, M.; Gschwend, J.; et al. Conventional NK cells and tissue-resident ILC1s join forces to control liver metastasis. BioRxiv 2020. [CrossRef]

92. Harmon, C.; Robinson, M.W.; Hand, F.; AlMuaili, D.; Mentor, K.; Houlihan, D.D.; Hoti, E.; Lynch, L.; Geoghegan, J.; O’Farrelly, C. Lactate-Mediated Acidification of Tumor Microenvironment Induces Apoptosis of Liver-Resident NK Cells in Colorectal Liver Metastasis. Cancer Immunol. Res. 2018, 7, 335-346. [CrossRef]

93. Dupaul-Chicoine, J.; Arabzadeh, A.; Dagenais, M.; Douglas, T.; Champagne, C.; Morizot, A.; Rodrigue-Gervais, I.G.; Breton, V.; Colpitts, S.L.; Beauchemin, N.; et al. The Nlrp3 Inflammasome Suppresses Colorectal Cancer Metastatic Growth in the Liver by Promoting Natural Killer Cell Tumoricidal Activity. Immunity 2015, 43, 751-763. [CrossRef] [PubMed]

94. Takeda, K.; Hayakawa, Y.; Smyth, M.J.; Kayagaki, N.; Yamaguchi, N.; Kakuta, S.; Iwakura, Y.; Yagita, H.; Okumura, K. Involvement of tumor necrosis factor-related apoptosis-inducing ligand in surveillance of tumor metastasis by liver natural killer cells. Nat. Med. 2001, 7, 94-100. [CrossRef] 
95. Donadon, M.; Hudspeth, K.; Cimino, M.; Di Tommaso, L.; Preti, M.; Tentorio, P.; Roncalli, M.; Mavilio, D.; Torzilli, G. Increased Infiltration of Natural Killer and T Cells in Colorectal Liver Metastases Improves Patient Overall Survival. J. Gastrointest. Surg. 2017, 21, 1226-1236. [CrossRef]

96. Krijgsman, D.; Hokland, M.; Kuppen, P.J.K. The Role of Natural Killer T Cells in Cancer-A Phenotypical and Functional Approach. Front. Immunol. 2018, 9, 367. [CrossRef]

97. Kee, J.-Y.; Ito, A.; Hojo, S.; Hashimoto, I.; Igarashi, Y.; Tsukada, K.; Irimura, T.; Shibahara, N.; Nakayama, T.; Yoshie, O.; et al. Chemokine CXCL16 suppresses liver metastasis of colorectal cancer via augmentation of tumor-infiltrating natural killer T cells in a murine model. Oncol. Rep. 2013, 29, 975-982. [CrossRef] [PubMed]

98. Ma, C.; Han, M.; Heinrich, B.; Fu, Q.; Zhang, Q.; Sandhu, M.; Agdashian, D.; Terabe, M.; Berzofsky, J.A.; Fako, V.; et al. Gut microbiome-mediated bile acid metabolism regulates liver cancer via NKT cells. Science 2018, 360, 876-885. [CrossRef]

99. Yang, W.; Li, H.; Mayhew, E.; Mellon, J.; Chen, P.W.; Niederkorn, J.Y. NKT Cell Exacerbation of Liver Metastases Arising from Melanomas Transplanted into Either the Eyes or Spleens of Mice. Investig. Opthalmology Vis. Sci. 2011, 52, 3094-3102. [CrossRef]

100. Katz, S.C.; Bamboat, Z.M.; Maker, A.V.; Shia, J.; Pillarisetty, V.G.; Yopp, A.C.; Hedvat, C.V.; Gonen, M.; Jarnagin, W.R.; Fong, Y.; et al. Regulatory T Cell Infiltration Predicts Outcome Following Resection of Colorectal Cancer Liver Metastases. Ann. Surg. Oncol. 2013, 20, 946-955. [CrossRef] [PubMed]

101. Kaplan, R.N.; Riba, R.D.; Zacharoulis, S.; Bramley, A.H.; Vincent, L.; Costa, C.; Macdonald, D.D.; Jin, D.K.; Shido, K.; Kerns, S.A.; et al. VEGFR1-positive haematopoietic bone marrow progenitors initiate the pre-metastatic niche. Nature 2005, 438, 820-827. [CrossRef] [PubMed]

102. Hiratsuka, S.; Nakamura, K.; Iwai, S.; Murakami, M.; Itoh, T.; Kijima, H.; Shipley, J.M.; Senior, R.M.; Shibuya, M. MMP9 induction by vascular endothelial growth factor receptor-1 is involved in lung-specific metastasis. Cancer Cell 2002, 2, 289-300. [CrossRef]

103. Bosman, F.T.; Stamenkovic, I. Functional structure and composition of the extracellular matrix. J. Pathol. 2003, 200, 423-428. [CrossRef] [PubMed]

104. Voss, H.; Wurlitzer, M.; Smit, D.J.; Ewald, F.; Alawi, M.; Spohn, M.; Indenbirken, D.; Omidi, M.; David, K.; Juhl, H.; et al. Differential regulation of extracellular matrix proteins in three recurrent liver metastases of a single patient with colorectal cancer. Clin. Exp. Metastasis 2020, 37, 649-656. [CrossRef]

105. Shen, Y.; Wang, X.; Lu, J.; Salfenmoser, M.; Wirsik, N.M.; Schleussner, N.; Imle, A.; Valls, A.F.; Radhakrishnan, P.; Liang, J.; et al. Reduction of Liver Metastasis Stiffness Improves Response to Bevacizumab in Metastatic Colorectal Cancer. Cancer Cell 2020, 37, 800-817.e7. [CrossRef]

106. Rahbari, N.N.; Kedrin, D.; Incio, J.; Liu, H.; Ho, W.W.; Nia, H.T.; Edrich, C.M.; Jung, K.; Daubriac, J.; Chen, I.; et al. Anti-VEGF therapy induces ECM remodeling and mechanical barriers to therapy in colorectal cancer liver metastases. Sci. Transl. Med. 2016, 8, 360ra135. [CrossRef] [PubMed]

107. Cools-Lartigue, J.; Spicer, J.; McDonald, B.; Gowing, S.; Chow, S.; Giannias, B.; Bourdeau, F.; Kubes, P.; Ferri, L. Neutrophil extracellular traps sequester circulating tumor cells and promote metastasis. J. Clin. Investig. 2013, 123, 3446-3458. [CrossRef]

108. Tohme, S.; Yazdani, H.O.; Al-Khafaji, A.B.; Chidi, A.P.; Loughran, P.; Mowen, K.; Wang, Y.; Simmons, R.L.; Huang, H.; Tsung, A. Neutrophil extracellular traps promote the development and progression of liver metastases after surgical stress. Cancer Res. 2016, 76, 1367-1380. [CrossRef]

109. Park, J.; Wysocki, R.W.; Amoozgar, Z.; Maiorino, L.; Fein, M.R.; Jorns, J.; Schott, A.F.; Kinugasa-Katayama, Y.; Lee, Y.; Won, N.H.; et al. Cancer cells induce metastasis-supporting neutrophil extracellular DNA traps. Sci. Transl. Med. 2016, 8, 361ra138. [CrossRef] [PubMed]

110. Wei, X.L.; Luo, X.; Sheng, H.; Wang, Y.; Chen, D.L.; Li, J.N.; Wang, F.H.; Xu, R.H. PD-L1 expression in liver metastasis: Its clinical significance and discordance with primary tumor in colorectal cancer. J. Transl. Med. 2020, 18, 475. [CrossRef]

111. Jabbari, N.; Kenerson, H.L.; Lausted, C.; Yan, X.; Meng, C.; Sullivan, K.M.; Baloni, P.; Bergey, D.; Pillarisetty, V.G.; Hood, L.E.; et al. Modulation of Immune Checkpoints by Chemotherapy in Human Colorectal Liver Metastases. Cell Rep. Med. 2020, 1, 100160. [CrossRef] [PubMed]

112. Fiegle, E.; Doleschel, D.; Koletnik, S.; Rix, A.; Weiskirchen, R.; Borkham-Kamphorst, E.; Kiessling, F.; Lederle, W. Dual CTLA-4 and PD-L1 Blockade Inhibits Tumor Growth and Liver Metastasis in a Highly Aggressive Orthotopic Mouse Model of Colon Cancer. Neoplasia 2019, 21, 932-944. [CrossRef]

113. Steele, G.; Bleday, R.; Mayer, R.J.; Lindblad, A.; Petrelli, N.; Weaver, D. A prospective evaluation of hepatic resection for colorectal carcinoma metastases to the liver: Gastrointestinal Tumor Study Group Protocol 6584. J. Clin. Oncol. 1991, 9, 1105-1112. [CrossRef]

114. Scheele, J.; Stang, R.; Altendorf-Hofmann, A.; Paul, M. Resection of colorectal liver metastases. World J. Surg. 1995, 19, 59-71. [CrossRef] [PubMed]

115. Cummings, L.C.; Payes, J.D.; Cooper, G.S. Survival after hepatic resection in metastatic colorectal cancer: A population-based study. Cancer 2007, 109, 718-726. [CrossRef] [PubMed]

116. Turrini, O.; Viret, F.; Guiramand, J.; Lelong, B.; Bege, T.; Delpero, J.R. Strategies for the treatment of synchronous liver metastasis. Eur. J. Surg. Oncol. 2007, 33, 735-740. [CrossRef]

117. Tomlinson, J.S.; Jarnagin, W.R.; DeMatteo, R.P.; Fong, Y.; Kornprat, P.; Gonen, M.; Kemeny, N.; Brennan, M.F.; Blumgart, L.H.; D’Angelica, M. Actual 10-Year Survival After Resection of Colorectal Liver Metastases Defines Cure. J. Clin. Oncol. 2007, 25, 4575-4580. [CrossRef] 
118. Misiakos, E.P.; Karidis, N.P.; Kouraklis, G. Current treatment for colorectal liver metastases. World J. Gastroenterol. 2011, 17, 4067-4475. [CrossRef]

119. Abdalla, E.K.; Vauthey, J.-N.; Ellis, L.M.; Ellis, V.; Pollock, R.; Broglio, K.R.; Hess, K.; Curley, S.A. Recurrence and Outcomes Following Hepatic Resection, Radiofrequency Ablation, and Combined Resection/Ablation for Colorectal Liver Metastases. Ann. Surg. 2004, 239, 818-827. [CrossRef]

120. Kalofonos, H.; Aravantinos, G.; Kosmidis, P.; Papakostas, P.; Economopoulos, T.; Dimopoulos, M.; Skarlos, D.; Bamias, A.; Pectasides, D.; Chalkidou, S.; et al. Irinotecan or oxaliplatin combined with leucovorin and 5-fluorouracil as first-line treatment in advanced colorectal cancer: A multicenter, randomized, phase II study. Ann. Oncol. 2005, 16, 869-877. [CrossRef]

121. Seium, Y.; Stupp, R.; Ruhstaller, T.; Gervaz, P.; Mentha, G.; Philippe, M.; Allal, A.; Trembleau, C.; Bauer, J.; Morant, R.; et al. Oxaliplatin combined with irinotecan and 5-fluorouracil/leucovorin (OCFL) in metastatic colorectal cancer: A phase I-II study. Ann Oncol. 2005, 16, 762-766. [CrossRef]

122. Grivicich, I.; Mans, D.R.; Peters, G.J.; Schwartsmann, G. Irinotecan and oxaliplatin: An overview of the novel chemotherapeutic options for the treatment of advanced colorectal cancer. Braz. J. Med. Biol. Res. 2001, 34, 1087-1103. [CrossRef]

123. Adam, R.; Avisar, E.; Ariche, A.; Giachetti, S.; Azoulay, D.; Castaing, D.; Kunstlinger, F.; Levi, F.; Bismuth, F. Five-year survival following hepatic resection after neoadjuvant therapy for nonresectable colorectal. Ann. Surg. Oncol. 2001, 8, 347-353. [CrossRef]

124. Adam, R.; Delvart, V.; Pascal, G.; Valeanu, A.; Castaing, D.; Azoulay, D.; Giacchetti, S.; Paule, B.; Kunstlinger, F.; Ghemard, O.; et al. Rescue surgery for unresectable colorectal liver metastases downstaged by chemotherapy: A model to predict long-term survival. Ann. Surg. 2004, 240, 644-657. [CrossRef]

125. Raoul, J.-L.; Van Laethem, J.-L.; Peeters, M.; Brezault, C.; Husseini, F.; Cals, L.; Nippgen, J.; Loos, A.-H.; Rougier, P. Cetuximab in combination with irinotecan/5-fluorouracil/folinic acid (FOLFIRI) in the initial treatment of metastatic colorectal cancer: A multicentre two-part phase I/II study. BMC Cancer 2009, 9, 112. [CrossRef]

126. Liu, L.-X.; Zhang, W.-H.; Jiang, H.-C. Current treatment for liver metastases from colorectal cancer. World J. Gastroenterol. 2003, 9 , 193-200. [CrossRef] [PubMed]

127. Lygidakis, N.J.; Sgourakis, G.; Dedemadi, G.; Safioleus, M.C.; Nestoridis, J. Regional chemoimmunotherapy for nonresectable metastatic liver disease of colorectal origin. A prospective randomized study. Hepatogastroenterology 2001, 48, $1085-1087$. [PubMed]

128. Raval, M.; Bande, D.; Pillai, A.K.; Blaszkowsky, L.S.; Ganguli, S.; Beg, M.S.; Kalva, S.P. Yttrium-90 radioembolization of hepatic metastases from colorectal cancer. Front Oncol. 2014, 4, 120. [CrossRef]

129. Mok, M.T.; Zhou, J.; Tang, W.; Zeng, X.; Oliver, A.W.; Ward, S.E.; Cheng, A.S. CCRK is a novel signalling hub exploitable in cancer immunotherapy. Pharmacol. Ther. 2018, 186, 138-151. [CrossRef] [PubMed]

130. Uhlén, M.; Fagerberg, L.; Hallström, B.M.; Lindskog, C.; Oksvold, P.; Mardinoglu, A.; Sivertsson, Å.; Kampf, C.; Sjöstedt, E.; Asplund, A.; et al. Tissue-based map of the human proteome. Science 2015, 347, 1260419. [CrossRef]

131. Yu, Z.; Gao, Y.Q.; Feng, H.; Lee, Y.Y.; Li, M.S.; Tian, Y.; Go, M.Y.; Yu, D.Y.; Cheung, Y.S.; Lai, P.B.; et al. Cell cycle-related kinase mediates viral-host signalling to promote hepatitis B virus-associated hepatocarcinogenesis. Gut 2014, 63, 1793-1804. [CrossRef]

132. Sun, H.; Yang, W.; Tian, Y.; Zeng, X.; Zhou, J.; Mok, M.T.S.; Tang, W.; Feng, Y.; Xu, L.; Chan, A.W.H.; et al. An inflammatory-CCRK circuitry drives mTORC1-dependent metabolic and immunosuppressive reprogramming in obesity-associated hepatocellular carcinoma. Nat. Commun. 2018, 9, 1-16. [CrossRef]

133. Feng, H.; Cheng, A.S.; Tsang, D.P.; Li, M.S.; Go, M.Y.; Cheung, Y.S.; Zhao, G.J.; Ng, S.S.; Lin, M.C.; Yu, J.; et al. Cell cycle-related kinase is a direct androgen receptor-regulated gene that drives beta-catenin/T cell factor-dependent hepatocarcinogenesis. J. Clin. Investig. 2011, 121, 3159-3175. [CrossRef]

134. Feng, H.; Yu, Z.; Tian, Y.; Lee, Y.-Y.; Li, M.S.; Go, M.Y.; Cheung, Y.-S.; Lai, P.B.; Chan, A.M.; To, K.-F.; et al. A CCRK-EZH2 epigenetic circuitry drives hepatocarcinogenesis and associates with tumor recurrence and poor survival of patients. J. Hepatol. 2015, 62, 1100-1111. [CrossRef] [PubMed]

135. Zhou, J.; Liu, M.; Sun, H.; Feng, Y.; Xu, L.; Chan, A.W.H.; Tong, J.H.; Wong, J.; Chong, C.C.N.; Lai, P.B.S.; et al. Hepatoma-intrinsic CCRK inhibition diminishes myeloid-derived suppressor cell immunosuppression and enhances immune-checkpoint blockade efficacy. Gut 2018, 67, 931-944. [CrossRef] [PubMed]

136. Greten, T.F.; Korangy, F. CDK20 inhibition and immune checkpoint blockade: Bringing cancer biology and tumour immunology together to develop novel treatment options for HCC. Gut 2017, 67, 783-784. [CrossRef]

137. Das, S.; Allen, A.; Berlin, J. Immunotherapy after Immunotherapy: Response Rescue in a Patient With Microsatellite Instabilityhigh Colorectal Cancer Post-Pembrolizumab. Clin. Colorectal. Cancer 2020, 19, 137-140. [CrossRef]

138. Binnewies, M.; Roberts, E.W.; Kersten, K.; Chan, V.; Fearon, D.F.; Merad, M.; Coussens, L.M.; Gabrilovich, D.I.; Ostrand-Rosenberg, S.; Hedrick, C.C.; et al. Understanding the tumor immune microenvironment (TIME) for effective therapy. Nat. Med. 2018, 24, 541-550. [CrossRef] [PubMed]

139. Yu, X.; Zhu, L.; Liu, J.; Xie, M.; Chen, J.; Li, J. Emerging Role of Immunotherapy for Colorectal Cancer with Liver Metastasis. OncoTargets Ther. 2020, 13, 11645-11658. [CrossRef] [PubMed]

140. Sur, D.; Havasi, A.; Cainap, C.; Samasca, G.; Burz, C.; Balacescu, O.; Lupan, I.; Deleanu, D.; Irimie, A. Chimeric Antigen Receptor T-Cell Therapy for Colorectal Cancer. J. Clin. Med. 2020, 9, 182. [CrossRef] [PubMed]

141. Medina-Echeverz, J.; Eggert, T.; Han, M.; Greten, T.F. Hepatic myeloid-derived suppressor cells in cancer. Cancer Immunol. Immunother. 2015, 64, 931-940. [CrossRef] [PubMed] 
142. Tanaka, K.; Adam, R.; Shimada, H.; Azoulay, D.; Lévi, F.; Bismuth, H. Role of neoadjuvant chemotherapy in the treatment of multiple colorectal metastases to the liver. Brit. J. Surg. 2003, 90, 963-969. [CrossRef] [PubMed]

143. Power, D.G.; Kemeny, N.E. Chemotherapy for the conversion of unresectable colorectal cancer liver metastases to resection. Crit. Rev. Oncol. Hematol. 2011, 79, 251-264. [CrossRef] 